University of Michigan Law School

University of Michigan Law School Scholarship Repository

Law \& Economics Working Papers

4-10-2017

\title{
Compensation for Expropriations in a World of Investment Treaties: Beyond the Lawful/Unlawful Distinction
}

\author{
Steven Ratner \\ University of Michigan Law School, sratner@umich.edu
}

Follow this and additional works at: https://repository.law.umich.edu/law_econ_current

Part of the Banking and Finance Law Commons, and the Law and Economics Commons

\section{Working Paper Citation}

Ratner, Steven, "Compensation for Expropriations in a World of Investment Treaties: Beyond the Lawful/ Unlawful Distinction" (2017). Law \& Economics Working Papers. 131.

https://repository.law.umich.edu/law_econ_current/131

This Article is brought to you for free and open access by University of Michigan Law School Scholarship Repository. It has been accepted for inclusion in Law \& Economics Working Papers by an authorized administrator of University of Michigan Law School Scholarship Repository. For more information, please contact mlaw.repository@umich.edu. 


\title{
COMPENSATION FOR EXPROPRIATIONS IN A WORLD OF INVESTMENT TREATIES: BEYOND THE LAWFUL/UNLAWFUL DisTinCtion
}

\author{
By Steven R. Ratner*
}

For much of the last century, global actors have sparred over the international legal rules governing the compensation a state should pay a foreign investor when it expropriates the latter's property. The competing claims have had many dimensions, including the content of customary international law and the line between bona fide regulations and expropriations. In the modern age of international investment agreements (IIAs), a debate continues over another key issue: When a state expropriates a foreign investment in violation of an IIA, where should a tribunal look for the standard of compensation - to the amount the treaty requires the state to pay when it expropriates, or to an external standard for violations of international law generally? Each is alluring to a tribunal for its legal visibility - one spelled out in the very text under examination, and one stemming from a venerable international court case. But they may point to significantly different results for the investor and the host state. And investor-state tribunals remain wildly inconsistent, even incoherent, in their choice and use of those standards. It remains a significant source of disagreement in contemporary investor-state arbitration. ${ }^{1}$

Today's debate arises from the basic terms of modern IIAs. They typically ban host states from expropriating foreign investors unless - or, we might say, permit such expropriations only if - the state meets four conditions. These treaty conditions are, to simplify, that the taking be (a) for a public purpose; (b) carried out in a nondiscriminatory manner; (c) in accordance with some kind of legal process; and (d) accompanied by payment of (usually) full compensation for the value of the expropriated asset, usually specified as of the date of the expropriation, often with more details regarding acceptable valuation techniques and interest. ${ }^{2}$ For the sake of simplicity, we can call the first three process conditions, as they govern the manner of the expropriation, and the fourth as a payment condition, as it governs the monetary output of the process. The state can force a surrender of the property by paying the investor an amount specified by a third party, i.e., in the treaty; yet it must follow certain criteria and cannot just pay the investor to waive those process rights. ${ }^{3}$ Satisfaction of those four criteria legitimates the transfer, but compensation alone does not. $^{4}$

* Bruno Simma Collegiate Professor of Law, University of Michigan Law School. I appreciate comments from Charles Brower, William Dodge, Zachary Douglas, Jeffrey Dunoff, James Hines, Rachael Kent, Kyle Logue, Sean Murphy, Amiyatosh Purnanandam, Mathias Reimann, Bruno Simma, and participants in the University of Michigan Law School Legal Theory Workshop. I thank Nicholas Ognibene and Peri Tenenbaum for excellent research assistance.

${ }^{1}$ See the differences between the majority and dissenting arbitrators in Quiborax v. Bolivia, $<8>$ ICSID $<8>$ Case No. ARB/06/2, Award and Partially Dissenting Opinion of Brigitte Stern (Sept. 16, 2015) [hereinafter Quiborax].

${ }^{2}$ See $<8>$ UNCTAD $<8>$, InTERNATIONAL InVESTMENT AgREEMENTS: Key ISSUES Volume I, UNCTAD/ITE/IIT/2004/10, 243-46 (2004).

${ }^{3}$ These two categories of restrictions in the IIA are similar to liability rules and property rules in the sense of Calabresi and Melamed, but not quite the same. Both of those rules are closely associated with court-ordered remedies (compensation in the former, injunction in the 
So now consider these scenarios where states expropriate:

(1) The host state expropriates consistent with all four treaty criteria, in which case the investor is unlikely to sue under an IIA (and should lose if it does).

(2) The host state expropriates in conformity with the three process conditions, but it does not pay the investor anything, or at least less than full compensation, which can prompt investor-state arbitration.

(3) The host state expropriates in conformity with only some of the process conditions, while also not paying, which can also lead to arbitration.

(4) The host state violates any or all of the process conditions while paying full compensation, a possibility that could, but probably will not, lead an investor to litigate over the flawed procedures.

Multiple layers of complexity can be added, including simultaneous violation of other IIA provisions. And the host state will often deny that it is expropriating at all, in which case the tribunal will need to make that threshold determination.

The inconsistency and incoherence in the case law arises, then, over whether the compensation should be based on the formula in the treaty ((d) above) - an internal standard; or customary international law, in particular that reflected in the International Law Commission's Articles on State Responsibility (ASRs) - an external standard. Under the latter, the state, for its violation of the treaty, must pay full reparation, which may be more than the amount in the treaty. Tribunals disagree over these options, but do not consider approaches beyond them.

To date, the jurisprudence has been dominated by an anachronistic and analytically unhelpful distinction between the compensation or damages to be paid for so-called "unlawful expropriations" and those for so-called "lawful expropriations"-concepts traceable to the venerable Chorzów Factory case reflexively cited by tribunals. ${ }^{5}$ Historically, the former has referred to expropriations that violate certain legal commitments the state has made (in treaties, or even contracts) and the latter to expropriations that respect those commitments. But the case law is replete with diverse definitions of the two terms. More important, tribunals disagree on whether the state expropriating "unlawfully" or "illegally" should have to pay more to the investor than when it expropriates "lawfully" or "legally" - and in particular whether the former triggers damages under customary law, whereas the latter leads only to the amount in the treaty.

To return to our four scenarios, tribunals in particular disagree as to whether Scenario 2 or Scenario 3, or both, are "unlawful expropriations" due to the state's violation of the treaty's requirements, whereas Scenario 1 is a "lawful expropriation" because the state has followed the treaty; and the consequences of that distinction for damages. Among the most significant

latter), whereas the IIA itself specifies the compensation for expropriation and generally investors do not have the ability to prevent takings by host states. $C f$. Joost PAUwelyn, Optimal Protection of International Law: NaVigating Between European Absolutism AND AMERICAN VOLUNTARISM 148-50 (2008) (using these terms to describe IIA protections).

${ }^{4}$ See Jules L. Coleman \& Jody Kraus, Rethinking the Theory of Legal Rights, 95 YALE L.J. 1335, 1348-57 (1986).

${ }^{5}$ Case Concerning the Factory at Chorzów, 1928 PCIJ Rep. (ser. A) No. 17 (Sept. 13) [hereinafter Chorzów Factory]. 
decisions to make and monetize the distinction is Yukos v. Russia, a case under the Energy Charter Treaty that regarded Russia's seizure of claimants' shares of the Russian oil giant as "unlawful" under Scenario 3 (indeed, it found none of the process conditions to be met) and awarded investors 50 billion dollars. ${ }^{6}$ Scholars have parsed the case law, but a normative theory for treating the various scenarios for violations, including any relevance to the lawful/unlawful distinction, remains elusive.

The fluidity in the law is also part of larger debates over the kinds of state action international investment agreements should regulate. The political economy of investment law has shifted from one focused on investor protection - in particular, Northern investment in the South - to one with greater attention to host state prerogatives ("policy space"), respect for human rights, and duties on (and not merely rights for) business entities. Consequently, the characterization of a state's taking of property and the consequences for the state from alternative characterizations of the taking assume great importance. How we compensate the investor in the context of takings will also affect our approach to remedies for other violations of IIAs, where the treaties are silent. This debate crosses the regimes of international investment law and state responsibility, raising important questions about the nature of international legal obligations and the consequences of their breach.

This article, then, attempts to cut through the confusion surrounding the choice of remedies for expropriations based on standards internal to an IIA or external to it, and the concomitant lawful/unlawful panacea, and to offer a theoretical framework for determining the remedies for them. The lawful/unlawful dichotomy - and the assumption that the distinction maps onto two alternative and exclusive remedies - is antiquated and normatively deficient. It is a story of tribunals grasping for familiar, but outdated, legal concepts that lack any analytical punch for determining compensation and that reflect a rigid sort of doctrinal thinking. Indeed, when IIAs and custom are viewed as a whole, it becomes clear the law does not point to a simple choice of one internal or external standard. We instead need to develop a new approach by considering explicitly the purposes of the rules for compensation for expropriation in the context of the contemporary foreign investment process.

I develop this thesis as follows. Part I looks back to the origin of the current doctrinal muddle, namely the multiple understandings attached to, and consequences of, "lawful" and "unlawful" expropriations. Part II provides the normative framework for analyzing various doctrinal approaches, setting forth five generally accepted goals for any remedies for expropriation. Part III examines the principal alternatives for determining damages in the event of treaty-violative expropriations and how each fares in terms of advancing the goals for remedies. Part IV then takes my preferred position for a new approach-one that keys the remedies to the nature of the expropriatory act vis-à-vis the four criteria in investment treatiesand considers its implications for damages. Part $\mathrm{V}$ considers the possibility of extending this framework to remedies for other IIA violations. I conclude with a few observations about the implications of my approach for the relationship between host state obligations and remedies in international investment law more generally.

Finally, a word on the scope of this study: The question of internal versus external standards for compensation is one of a number of issues facing the international law of

${ }^{6}$ See Yukos Universal Ltd. v. Russian Fed'n, $<8>$ UNCITRAL $<8>$, PCA Case No. AA 227 (July 18, 2014), set aside, Russian Fed'n v. Veteran Petroleum Ltd., Yukos Universal Ltd., and Hulley Enterprises Ltd., Hague Dist. Ct. (Apr. 20, 2016) [hereinafter Yukos]. 
expropriation. To keep the focus on this issue, I will need to bracket other issues, already the subject of significant scholarship, including the contours of the law on indirect expropriation (regulatory takings), the possibility of a lesser payment to the investor after large-scale expropriations, the deference due to local procedures for providing compensation, and the types of property that may or may not be subject to expropriation.

\section{A LOOK BACK AT A CONFOUNDING Distinction}

The current state of the case law originates in, and still cites with regularity, a line of cases that emphasized the distinction between lawful and unlawful expropriations. Those cases are often cited by advocates, invoked by courts, or endorsed by scholars, many times with little appreciation of the different meanings the two key terms assumed over time.

\section{A. The Pre-IIA Era}

\section{From Chorzów Factory to the Oil Expropriation Cases}

If we had to assign a birth date to the lawful/unlawful distinction, it would probably be September 13, 1928, when the Permanent Court of International Justice (PCIJ) issued its ruling on the indemnity Poland had to pay to Germany for the former's seizure of the German-owned nitrate plant in Upper Silesia in the Case Concerning the Factory at Chorzów. That case has long stood for an authoritative pronouncement of the basic duty on a state that breaches its legal duties to provided full reparation-more specifically, for a remedy that serves to "wipe out all the consequences" of the breach—a position endorsed in the ILC's ASRs. But it has also generated countless citations for its passages that attempt to: (a) define, and set up the distinction between, lawful and unlawful expropriations; and (b) quantify that difference through a series of instructions by the judges to outside experts regarding the calculation of damages.

The PCIJ had already determined in 1926 that Poland's seizure of the German-owned factory violated the 1922 Geneva Convention Concerning Upper Silesia that prohibited most taking of foreign property. ${ }^{7}$ Indeed, in that phase of the case, it interpreted the Convention to the effect that if a taking were not in conformity with Articles 6-24 of that treaty, "expropriation is unlawful." In 1928, as it turned to the question of damages, it characterized that violation as follows:

The action of Poland ... contrary to the Geneva Convention is not an expropriation-to render which lawful only the payment of fair compensation would have been wanting; it is a seizure of property . . . which could not be expropriated even against compensation, save under the exceptional conditions fixed by Article 7 of the said Convention [i.e., with the permission of a mixed commission for the first fifteen years]. . . [R]eparation is in this case the consequence not of the application of Articles 6 to 22 of the Geneva Convention, but of acts contrary to those articles. ${ }^{9}$

${ }^{7}$ Certain German Interests in Polish Upper Silesia (Ger. v. Pol.), 1926 PCIJ Rep. (ser. A) No. 7 (May 25).

${ }^{8} I d$. at 21 .

${ }^{9}$ Chorzów Factory, supra note 5, at 46. 
In the next two paragraphs, it reiterated the distinction between a "lawful liquidation" and an "unlawful dispossession" or "illegal act." Thus, the central defining feature of the unlawful expropriation of the factory was that Poland violated the Geneva Convention, as previously determined by the Court. If Poland had taken over foreign property according to the terms of the treaty, it would have been a lawful expropriation.

For the PCIJ, this distinction had direct consequences for the damages due Germany. In its key holding, it said:

[T]he compensation due to the German Government is not necessarily limited to the value of the undertaking at the moment of dispossession, plus interest to the day of payment. This limitation would only be admissible if the Polish Government had had the right to expropriate, and if its wrongful act consisted merely in not having paid to the two Companies the just price of what was expropriated; in the present case, such a limitation might result in placing Germany and the interests protected by the Geneva Convention . . . in a situation more unfavourable than that in which Germany and these interests would have been if Poland had respected the said Convention. Such a consequence would not only be unjust, but . . incompatible with the aim of the . . Convention-that is to say, the prohibition, in principle, of the liquidation of the property . . . of German nationals and ... companies ... . in Upper Silesia - since it would be tantamount to rendering lawful liquidation and unlawful dispossession indistinguishable in so far as their financial results are concerned. ${ }^{10}$

One should notice three core points from this passage. First, the Court seems to posit that the amount due Germany for a lawful expropriation was the "value of the undertaking at the moment of dispossession" (plus interest), which it calls the "just price of what was expropriated." I will call that value $\mathrm{FV}_{\mathrm{DE}}$, for "full value on the date of expropriation." 11 Second, the Court is adamant that, as a matter of justice, the unlawful expropriation must be compensated at a higher level than the lawful compensation. Third, and somewhat confusingly, the Court suggests that if Poland's "wrongful act" had merely been nonpayment of the value at the moment of the taking, that amount would be all that was due-even though it would seem that a denial of payment is wrongful as well.

From this starting point, the Court then developed its famous holding that a remedy for unlawful acts must "wipe out all the consequences" of them. ${ }^{12}$ It then instructed experts to quantify this amount, though its instructions reflected antiquated understandings of the value of an asset - with physical and other committed assets (damnum emergens) and lost profits (lucrum cessans) separated out. It offered two valuation options that have flummoxed arbitrators, academics, and valuation experts ever since-(a) one that seems based on the sum of $\mathrm{FV}_{\mathrm{DE}}$ (or maybe just the damnum emergens) plus profits from the date of expropriation to the date of the award; and (b) another based on the value of the undertaking (or again, maybe just the damnum

${ }^{10}$ Id. at 47 .

${ }^{11}$ I leave aside for now whether that full value is based solely on information at the time of the expropriation or information that later became available. In any case, it should not reflect any change in value due to knowledge of the expropriation before it actually occurred.

${ }^{12}$ Chorzów Factory, supra note 5, at 47. 
emergens) at the time of the award. ${ }^{13}$ The Court never directly explained exactly how its "wipe out all the consequences" standard would provide a different level of compensation from the "value of the undertaking at the moment of dispossession," though, as discussed below, some read it to imply that the two formulas offered above can result in a higher award for the latter than the former. ${ }^{14}$

The major arbitrations concerning the nationalizations of Western oil interests in the Middle East in the 1960s and 1970s invoked Chorzów Factory's distinction between lawful and unlawful expropriations. In BP Exploration v. Libya (1973), where no treaty governed Libya's treatment of foreign investment, the sole arbitrator, Gunnar Lagergren, was careful to distinguish Chorzów Factory as a case concerned solely with expropriations in violation of treaties. ${ }^{15} \mathrm{He}$ referred to Libya's expropriation as a "wrongful act" by virtue of its breach of the concession agreement, but not as a wrongful or unlawful expropriation. ${ }^{16}$ As a result, he rejected BP's claims that it was entitled to full enjoyment of its rights under the concession. The parties settled before an award on damages was issued.

However, four years later, in Texas Overseas Petroleum Company (TOPCO) v. Libya (1977), arbitrator René-Jean Dupuy found that the claimant's contract with Libya was an "internationalized contract," and that Libya breached its duty under both Libyan and international law (both of which governed the concession agreement) to perform it. ${ }^{17}$ Dupuy turned to Chorzów Factory, other cases, and scholars, and ruled that the proper remedy for an "unlawful act" was nothing less than restitutio in integrum - full performance of the contracts it had breached. ${ }^{18}$ That rather audacious ruling has not been followed in an expropriation case since. ${ }^{19}$ In relying on remedies for an unlawful act, Dupuy thus suggested that an expropriation could be unlawful as a matter of customary international law merely if it violated a contract between the host state and the foreign investor. ${ }^{20}$

In two other leading cases, Libyan American Oil Company v. Libya (1977) and Kuwait v. American Independent Oil Company (1982), the arbitrators also distinguished between lawful and unlawful expropriations, in both cases rejecting the characterization of the respondent state's act as unlawful and adopting a damages formula that they claimed reflected the investors'

${ }^{13} I d$. at $51-52$.

${ }^{14}$ For a charitable interpretation, see Manuel A. Abdala \& Pablo T. Spiller, Chorzów's Standard Rejuvenated: Assessing Damages in Investment Treaty Arbitration, 25 J. INT'L ARB. 103, 105-08 (2008).

${ }^{15}$ BP Exploration Co. (Libya) Ltd. v. Libyan Arab Rep., 53 ILR 297, 337-40 (1973).

${ }^{16} \mathrm{Id}$. at $329,355$.

${ }^{17}$ Texas Overseas Petroleum Co. $(<8>$ TOPCO $<8>)$ v. Libyan Arab Rep., 17 ILM 1, paras. 93-109 (1977).

${ }^{18}$ Id., para. 103; see also id., paras. 97-109, dispositif.

${ }^{19}$ See Rosalyn Higgins, The Taking of Property by the State: Recent Developments in International Law, 176 RECUEIL DES COURS 259, 321 (1982) (favoring restitution in principle but finding "very little evidence that [it] is perceived as a required remedy or that it is anticipated as being likely to be granted.").

${ }^{20}$ For academic endorsement of an unlawful taking as one violating a concession agreement, see C.F. Amerasinghe, Issues of Compensation for the Taking of Alien Property in the Light of Recent Cases and Practice, 41 INT’L. \& COMP. L.Q. 22, 37 (1992). 
expectations. ${ }^{21}$ So while the distinction developed between the two sorts of characterizations remained, the one suggested by Dupuy in TOPCO remained the outlier.

\section{The Iran-U.S. Claims Tribunal}

Other than Chorzów Factory, the most significant case law addressing lawful/unlawful expropriations took place in the Iran-U.S. Claims Tribunal, in cases still cited by counsel and tribunals. The Tribunal was charged under the 1981 Algiers Accords with adjudicating claims of "expropriations or other measures affecting property rights"; the law for determining those claims included the U.S.-Iran Treaty of Amity, Economic Relations, and Consular Rights of $1955^{22}$ The context for addressing the distinction was Iran's argument in many cases that if a state engaged in a lawful expropriation - which it insisted was the correct characterization of its acts against U.S. companies - it need not pay full value (even $\mathrm{FV}_{\mathrm{DE}}$ ) to the investor, but rather significantly less or even nothing at all. ${ }^{23}$ Two cases demonstrate the allure of Chorzów Factory's distinctions to the tribunal.

In INA v. Iran (1985), the Tribunal addressed the claim of an American insurance company for the expropriation of its Iranian subsidiary. The panel noted that

expropriations for a public purpose and subject to conditions provided for by lawnotably that category which can be characterised as 'nationalisations'-are not per se unlawful. A lawful nationalisation will, however, impose on the government concerned the obligation to pay compensation. ${ }^{24}$

It did not, however, explain the connection between a breach of the Treaty of Amity and an unlawful expropriation. While the Tribunal admitted that a full-scale nationalization might not require full compensation, both treaty and custom demanded it in the case of the small-scale taking of INA (which it suggested, but did not actually say, was lawful). In separate opinions,

${ }^{21}$ Libyan Am. Oil Co. (Liamco) v. Libya, 20 ILM 1, 59, 61, 76-77 (1981); State of Kuwait v. Am. Indep. Oil Co., 21 ILM 976, 1024, paras. 102, 104; 1025, paras. 109-110; 1031, para. 138; 1034, paras. 148-49 (1982).

${ }^{22}$ Declaration of the Government of the Democratic and Popular Republic of Algeria Concerning the Settlement of Claims Between the Government of the United States of America and the Government of the Islamic Republic of Iran, Art. II, Jan. 19, 1981; Treaty of Amity, Economic Relations, and Consular Rights, U.S.-Iran, Aug. 15, 1955, 284 UNTS 93. Article 4(2) of the latter provides that property of nationals of each state "shall not be taken except for a public purpose, nor shall it be taken without the prompt payment of just compensation."

${ }^{23}$ See Martin J. Valasek, A "Simple Scheme": Exploring the Meaning of Chorzów Factory for the Valuation of Opportunistic Expropriation in the BIT Generation, 4 TDM 6, 42 (2007); see generally Matti Pellonpää, Compensable Claims Before the Tribunal: Expropriation Claims, in The Iran-United States Claims Tribunal: Its Contribution to the Law of State ResPonsibiLity 185, 198-217 (Richard B. Lillich \& Daniel Barstow Magraw eds., 1998).

${ }^{24}$ INA Corp. v. Islamic Rep. of Iran, Case No. 161, 8 Iran-U.S. Claims Trib. Rep. 373, 378 (Aug. 12, 1985). 
three arbitrators discussed the different levels of compensation for lawful versus unlawful takings. $^{25}$

The most extended discussion of the issue took place in Amoco International Finance (AIF) v. Iran (1987), concerning Iran's seizure of AIF's 50 percent interest in Khemco, which produced natural gas and related products. ${ }^{26}$ Of all the Tribunal's cases, this one still garners the most attention on the internal/external standard for compensation and lawful/unlawful distinction. The Tribunal applied the Treaty of Amity to Iran's acts, in each case finding no violation and concluding it was not unlawful for those reasons. ${ }^{27}$ Thus the Tribunal made a clear linkage between illegality and breach of a treaty. ${ }^{28}$ The conclusion that the expropriation was lawful proved critical for the Tribunal's views on the source of the standard for compensation:

Article IV, paragraph 2 of the Treaty determines the conditions that an expropriation should meet in order to be in conformity with its terms and therefore defines the standard of compensation only in case of a lawful expropriation. A nationalization in breach of the Treaty, on the other hand, would render applicable the rules relating to State responsibility, which are to be found not in the Treaty but in customary law. ${ }^{29}$

Even though the Tribunal had found the expropriation lawful, it turned to Chorzów Factory as "also illuminating." "30 It then reinterpreted the questions that the PCIJ had put to the experts to elaborate on the difference between the damages for a lawful expropriation compared to an unlawful one. In a ruling that seemed to lack much understanding of valuation methods, it concluded that lost profits were to be included as damages only for unlawful expropriations, and

${ }^{25}$ Id. at 385-90 (Lagergren, sep. op.) (calling discriminatory expropriations "inherently unlawful" and entitling investor to damages "as closely as possible in monetary terms to . . . restitutio in integrum," while large-scale nationalizations may call for less than full compensation); id. at 393-401 (Holtzmann, sep. op.) (disagreeing with Lagergren's latter proposition); id. at 411 (Ameli, dissenting) (unlawful measures involving breach "of its international obligations" including "its contractual obligations," may allow for restitutio in integrum). See also Sedco v. Nat'l Iranian Oil Co. and the Islamic Rep. of Iran, Case No. 129, 10 Iran-U.S. Claims Trib. Rep. 180, 187 (Mar. 27, 1986) (full value applies to a "discrete expropriation of alien property," "whether or not the expropriation itself was otherwise lawful") [hereinafter Sedco].

${ }^{26}$ Amoco Int'l Fin. Corp. (AIF) v. Islamic Rep. of Iran, Case. No. 56, 15 Iran-U.S. Claims Trib. Rep. 189 (July 14, 1987) [hereinafter $A I F]$.

${ }^{27} \mathrm{Id}$. at 234 , para. 147.

${ }^{28}$ It further found the breach of the contract by AIF's Iranian partner was not an unlawful act by Iran because Iran was not party to the contract, concluding that AIF's interests were "lawfully expropriated by Iran." This second finding suggests indirectly that illegality can arise from a breach of contract as well. Id. at 244, para. 182.

${ }^{29} \mathrm{Id}$. at 246 , para. 189.

${ }^{30} \mathrm{Id}$. at 247, para. 195. 
seemed to rule out discounted cash flow (DCF) as a method of valuation. Yet it then went ahead and applied a DCF evaluation after all. ${ }^{31}$

That dicta elicited a lengthy concurring opinion from Judge Brower. He accepted the idea of a distinction between lawful and unlawful expropriation, but offered a different interpretation of Chorzów Factory:

If an expropriation is lawful, the deprived party is to be awarded damages equal to "the value of the undertaking" which it has lost, including any potential future profits, as of the date of taking; in the case of an unlawful taking, however, either the injured party is to be actually restored to enjoyment of his property, or, should this be impossible or impractical, he is to be awarded damages equal to the greater of (i) the value of the undertaking at the date of loss (again including lost profits), judged on the basis of information available as of that date, and (ii) its value (likewise including lost profits) as shown by its probable performance subsequent to the date of loss and prior to the date of the award, based on actual post-taking experience, plus (in either alternative) any consequential damages. Apart from the fact that this is what Chorzów Factory says, it is the only set of principles that will guarantee just compensation . . . ${ }^{32}$

Both the majority and the concurrence thus resurrected Chorzów Factory's distinction between lawful and unlawful expropriations, and agreed that it affected the amount to be paid the investor, even though the majority thought it was only about whether to include lost profits. Brower's innovation was to read Chorzów Factory to mean that the target of the unlawful expropriation could choose the date of valuation. The investor could pick the larger of :(a) the $\mathrm{FV}_{\mathrm{DE}}$, as valued according to modern $\mathrm{DCF}$ techniques, and thus not limited to damnum emergens; and (b) the full value on the date of the award-which I will call $\mathrm{FV}_{\mathrm{DA}}$ - again as valued according to modern DCF techniques. ${ }^{33}$

Scholars and arbitrators have spilled much ink on whether the majority or Judge Brower interpreted Chorzów Factory correctly. ${ }^{34}$ I will not go down that route because, in the end, that exercise involves an interpretation of a part of the PCIJ judgment based on an anachronistic method of valuation, one that separated out damnum emergens and lucrum cessans, rather than modern financial terms. ${ }^{35}$ Chorzów Factory's valuation formulas reached their expiration date decades ago.

The pre-IIA era thus left a legacy of doctrinal messiness. Tribunals seized on the lawful/unlawful distinction but disagreed on: (a) the criteria for illegality (e.g., breach of a

${ }^{31} I d$. at 248-52, paras. 197-206; 258-64, paras. 227-46. For excellent critiques, see William C. Lieblich, Determinations by International Tribunals of the Economic Value of Expropriated Enterprises, 7 J. INT'L ARB. 37, 57-67 (1990); Valasek, supra note 23, at 16-20.

${ }^{32}$ AIF, supra note 26 , at 300-01, para. 18 (Brower, concurring).

${ }^{33}$ The Tribunal elaborated a bit on the distinction a few years later, holding that even lawful expropriations required payment of full value, while unlawful expropriations might require either restitution or payment for "any increase in the value of the property between the date of taking and the date of the [award]." Phillips Petroleum Co. Iran v. Islamic Rep. of Iran, Case No. 39, 21 Iran-U.S. Claims Trib. Rep. 79, 122, para. 110 (June 29, 1989).

${ }^{34}$ For a recent example, see the competing opinions in Quiborax, supra note 1.

${ }^{35}$ I elaborate on this point in Part IV.A below. 
contract, breach of a treaty, or other factors like discriminatory conduct); and (b) the consequences for damages, e.g., whether one or the other entitled the investor to restitutio in integrum, $\mathrm{FV}_{\mathrm{DA}}, \mathrm{FV}_{\mathrm{DE}}$, or even something much less.

\section{B. Enter the IIA Era}

One might have thought that tribunals adjudicating IIA claims could shed references to lawful or unlawful expropriations. Those meeting the criteria in the treaty would either not lead to litigation or not lead to any liability; and expropriations in violation of the treaty would be identified as treaty violations first and foremost. The remedy for those violations might be a based on a lex specialis for investment law (even in the treaty itself) or on the fallback position of customary law, but the lodestar of the analysis would be that the treaty had been violated. ${ }^{36}$

Yet counsel to investor-state disputes and many tribunals still deploy the distinction terminologically and substantively. The range of tribunal views, and the diversity of investments valued in current arbitrations, makes each case unique and grouping them somewhat difficult. ${ }^{37}$ Moreover, we can never be certain whether the stated position of the tribunal is actually doing any work in arriving at the final damages number given the mystery involved in those figures. Nonetheless, four basic positions seem to have emerged: ${ }^{38}$

Group 1-Compensation Based on Treaty Formula, Silence on the Lawful/Unlawful Distinction: Numerous IIA cases have found that the state expropriated the claimant's investment in violation of an IIA and yet did not rely on any distinction between lawful and unlawful expropriations in their award of damages. The tribunals avoided addressing the distinction and turned to the treaty standard of $\mathrm{FV}_{\mathrm{DE}}$ as the basis for damages. These include: Metalclad v. Mexico (2000); ${ }^{39}$ Wena Hotels v. Egypt (2000); ${ }^{40}$ Middle East Cement v. Egypt (2002); ${ }^{41}$ Tecmed v. Mexico (2004); ${ }^{42}$ Rumeli Telekom v. Kazakhstan (2008); ${ }^{43}$ Sistem Muhendislik Insaat Sanayi ve Ticaret v. Kyrgyz Republic (2009); ${ }^{44}$ Occidental Petroleum $v$. Ecuador (2012); ${ }^{45}$ Abengoa y Cofides v. Mexico (2013); ${ }^{46}$ SAUR v. Argentina (2014); ${ }^{47}$ and Tenaris and Talta-Trading E Marketing v. Venezuela (2016). ${ }^{48}$

${ }^{36}$ Arbitrations whose governing law was customary international law or a state's domestic law would still need to adopt the distinction.

${ }^{37}$ See Meg Kinnear, Damages in Investment Treaty Arbitration, in ARBITRATION Under International Investment Agreements: A Guide to The Key Issues 551, 559-60 (Katia Yannaca-Small ed., 2010).

${ }^{38}$ Unless otherwise noted, the treaty standard in all of the cases discussed here was the $\mathrm{FV}_{\mathrm{DE}}$, so differences in treaty language do not account for the different approaches to remedies.

$39<8>$ ICSID $<8>$ Case No. ARB(AF)/97/1, para. 118 (Aug. 30, 2000).

${ }^{40}<8>$ ICSID $<8>$ Case No. ARB/98/4, para. 118 (Dec. 8, 2000) [hereinafter Wena Hotels].

${ }^{41}<8>$ ICSID $<8>$ Case No. ARB/99/6, paras. 144, 146 (Apr. 12, 2002).

$42<8>$ ICSID $<8>$ Case No. ARB(AF) $/ 00 / 2$, paras. 151, 187-88 (May 29, 2003).

${ }^{43}<8>$ ICSID $<8>$ Case No. ARB/05/16, para. 785 (July 29, 2008) [hereinafter Rumeli Telekom].

$44<8>$ ICSID $<8>$ Case No. ARB(AF)/06/1, paras. 121, 156, 159 (Sept. 9, 2009).

$45<8>$ ICSID $<8>$ Case No. ARB/06/11, para. 707 (Oct. 5, 2012).

$46<8>$ ICSID $<8>$ Case No. ARB(AF)/09/2, para. 681 (Apr. 18, 2013). 
Group 2-Lawful/Unlawful Distinction Noted, but Damages the Same as a Legal Matter: In other cases, tribunals noted the distinction but found that it did not, as a matter of law, have an effect on damages. In general, these cases found the customary international law standard to be the same as the treaty standard and awarded $\mathrm{FV}_{\mathrm{DE}}$. Notable among these are: $C M E v$. Czech Republic (2001-03); ${ }^{49}$ Gemplus and Talsud v. Mexico (2010) ${ }^{50}$ Unglaube v. Costa Rica (2012); ${ }^{51}$ Guaracachi v. Bolivia (2014); ${ }^{52}$ British Caribbean Bank v. Belize (2014); ${ }^{.3}$ and Rusoro Mining v. Venezuela. ${ }^{54}$

Group 3-Lawful/Unlawful Distinction Noted, but Treaty Formula Used Due to Special Facts: In a third set of cases, tribunals accepted that lawful versus unlawful expropriations would produce different damages; but they did not rely on the distinction in the award due to the specific traits of the investment. Key cases include: Funnekotter v. Zimbabwe (2009); ${ }^{55}$ Siag and Vecchi v. Egypt (2009); ${ }^{.6}$ Kardassopoulos v. Georgia (2010); ${ }^{57}$ Houben v. Burundi $(2016) ;{ }^{58}$ Crystallex International v. Venezuela $;{ }^{59}$ and Vestey Group v. Venezuela. ${ }^{60}$

$47<8>$ ICSID $<8>$ Case No. ARB/04/4, para. 85 (Mar. 22, 2014). See also Alpha Projektholding v. Ukraine, $<8>$ ICSID $<8>$ Case No. ARB/07/16, paras. 481-93 (Nov. 8, 2010); Goetz v. Burundi, $<8>$ ICSID $<8>$ Case No. ARB/01/2, para. 295 (June 21, 2012) (both endorsing $\mathrm{FV}_{\mathrm{DE}}$ without mention of a treaty standard); Santa Elena v. Costa Rica, $<8>$ ICSID $<8>$ Case No. ARB/96/1, paras. 78-84 (Feb. 17, 2000) (endorsing FV $\mathrm{F}_{\mathrm{DE}}$ but no IIA governing dispute).

${ }^{48}<8>$ ICSID $<8>$ Case No. ARB/11/26, paras. 512-17 (Jan. 29, 2016) [hereinafter Tenaris].

$49<8>$ UNCITRAL $<8>$, Partial Award, paras. 615-16 (Sept. 13, 2001); Final Award, paras. 494-508 (Mar. 14, 2003) (treaty standard of "just compensation" is amount under customary law, which was $\left.\mathrm{FV}_{\mathrm{DE}}\right)$.

${ }^{50}<8>$ ICSID $<8>$ Case Nos. ARB(AF)/04/3 and 04/4, paras. 8-25, 12-43, 12-53, 13-93 (June 16, 2010) (treaty standard a "useful guide" for compensation for unlawful expropriations and investment valued as of date of expropriation) [hereinafter Unglaube].

${ }^{51}<8>$ ICSID $<8>$ Case No. ARB/08/1, paras. 305-18 (May 16, 2012) (treaty and custom generally require valuation of asset at highest fair market value).

$52<8>$ UNCITRAL $<8>$, PCA Case No. 2011-17, paras. 441, 443-44, 613-14 (Jan. 31, 2014) (hinting that $\mathrm{FV}_{\mathrm{DA}}$ might apply in principle).

$53<8>$ UNCITRAL $<8>$, PCA Case No. 2010-18, paras. 241, 260-61 (Dec. 19, 2014) (BIT's standard of $\mathrm{FV}_{\mathrm{DE}}$ a lex specialis regardless of whether expropriation was lawful or unlawful, but awarding no expropriation damages based on absence of evidence from claimant) [hereinafter British Caribbean Bank]. For two cases where the tribunal called the expropriation illegal but relied on the treaty without explanation, see OI European Grp. v. Venezuela, $<8>$ ICSID $<8>$ Case No. ARB/11/25, paras. 426, 647 (Mar. 10, 2015); Flughafen Zurich v. Venezuela, $<8>$ ICSID $<8>$ Case No. ARB/10/19, paras. 744-47 (Nov. 18, 2014).

${ }^{54}<8>$ ICSID $<8>$ Case No. ARB(AF)/12/5, paras. 639-40, 646 (Aug. 22, 2016).

$55<8>$ ICSID $<8>$ Case No. ARB/05/6, paras. 108-23 (Apr. 22, 2009) (using treaty standard of "genuine value," interpreted to be $F V_{D E}$, because investment had not appreciated since its taking).

${ }^{56}<8>$ ICSID $<8>$ Case No. ARB/05/15, paras. 443, 539-41 (June 1, 2009) (using $\mathrm{FV}_{\mathrm{DE}}$ because investors not seeking loss of profits per se) [hereinafter Siag \& Vecchi]. 
Group 4-Lawful/Unlawful Distinction Noted, with an Effect on Damages: Finally, in a relatively small number of cases, the tribunal has both made a distinction between the two types of takings and used that distinction as the lodestar for determining damages. The seven cases are: ADC v. Hungary (2006); ${ }^{61}$ Siemens v. Argentina (2007); ${ }^{62}$ ConocoPhillips $v$. Venezuela (2013); ${ }^{63}$ Yukos Universal v. Russia (2014); ${ }^{64}$ Venezuela Holdings v. Venezuela (2014); ${ }^{65}$ Tidewater v. Venezuela (2015); ${ }^{66}$ and Quiborax v. Bolivia (2015). ${ }^{67}$ Of the seven

$57<8>$ ICSID $<8>$ Case No. ARB/05/18, paras. 514-17 (Mar. 3, 2010) (applying treaty standard of $\mathrm{FV}_{\mathrm{DE}}$ on the grounds that claimants would have sold their business at that time).

${ }^{58}<8>$ ICSID $<8>$ Case No. ARB/13/7, paras. 219-26, 236-39 (Jan. 12, 2016) (using FV $\mathrm{DV}_{\mathrm{DE}}$ because claimant could not prove consequential damages or an increase in value of the investment).

${ }^{59}<8>$ ICSID $<8>$ Case No. ARB(AF)/11/2, paras. 841-53 (Apr. 4, 2016) (applying $\mathrm{FV}_{\mathrm{DE}}$ because parties agree on valuation date).

${ }^{60}<8>$ ICSID $<8>$ Case No. ARB/06/4, paras. 329-31, 350, 437-40 (Apr. 15, 2016) (applying $\mathrm{FV}_{\mathrm{DE}}$ because parties agree on valuation date) [hereinafter Vestey].

${ }^{61}<8>$ ICSID $<8>$ Case No. ARB/03/16, paras. 426-44, 481, 483-99 (Oct. 2, 2006) (finding BIT violation an "unlawful expropriation," applying Chorzów Factory, and calculating damages based on $\mathrm{FV}_{\mathrm{DA}}$ ) [hereinafter $A D C$ ]. On the difference in the award from using $\mathrm{FV}_{\mathrm{DA}}$, see Valasek, supra note 23.

$62<8>$ ICSID $<8>$ Case No. ARB/02/8, paras. 349, 352, 360 (Feb. 6, 2007) (breach of BIT renders expropriation "unlawful," requiring payment of $\mathrm{FV}_{\mathrm{DA}}$ plus consequential damages, but basing $\mathrm{FV}_{\mathrm{DA}}$ on book value as of date of expropriation) [hereinafter Siemens].

${ }^{63}<8>$ ICSID $<8>$ Case No. ARB/07/30, paras. 342-43, 362, 401 (Sept. 3, 2013) (BIT's compensation criterion requires only that host state negotiate with investor in good faith over compensation, but concluding that Venezuela had failed to do so, leading to an unlawful expropriation and damages based on $\mathrm{FV}_{\mathrm{DA}}$ ) [hereinafter ConocoPhillips]. The tribunal has not issued an award on the quantum due to attempts by Venezuela to remove two arbitrators.

${ }^{64}$ Yukos, supra note 6, paras. 1581-85, 1758-69, 1826-27 (breach of Energy Charter Treaty an "unlawful expropriation," triggering Chorzów Factory and the Articles on Responsibility of States for Internationally Wrongful Acts, and allowing claimant to choose between $\mathrm{FV}_{\mathrm{DE}}$ and $\left.\mathrm{FV}_{\mathrm{DA}}\right)$.

${ }^{65}<8>$ ICSID $<8>$ Case No. ARB 07/27, paras. 301-06 (Oct. 9, 2014) (expropriation did not violate BIT requirement of "just compensation" because state had made a serious proposal to the investor for compensation, and awarding $\mathrm{FV}_{\mathrm{DE}}$, also specified in the BIT); annulled, Mar. 9, 2017 [hereinafter Venezuela Holdings].

${ }^{66}<8>$ ICSID $<8>$ Case. No. ARB/10/5, paras. 140-46, 159-63 (Mar. 13, 2015) (holding that "an expropriation only wanting fair compensation has to be considered as a provisionally lawful expropriation," which was the case here because Venezuelan law required state to pay investor only book value, and calculating damages based on BIT's standard of FV $\mathrm{DE}_{\mathrm{DE}}$ ) [hereinafter Tidewater].

${ }^{67}$ Quiborax, supra note 1, paras. 240-55, 325-30, 343-47, 370-85 (BIT violation triggers remedy under Chorzów Factory and the Articles on Responsibility of States for Internationally Wrongful Acts, interpreted as $\left.\mathrm{FV}_{\mathrm{DA}}\right)$. 
cases, the tribunal found the action unlawful in five cases-ADC, Siemens, ConocoPhillips, Yukos, and Quiborax - and lawful in two-Venezuela Holdings and Tidewater.

The modern IIA cases thus evidence a significant range of approaches to the use of internal versus external standards regarding compensation for expropriation and the relevance of the lawful/unlawful distinction. Nonetheless, most tribunals distinguish between a lawful and unlawful expropriation, and those tribunals doing so equate "unlawful" with an expropriation in violation of the IIA's criteria. The other uses suggested in the earlier case law (e.g., a violation of custom, or a contract) have faded. Still, most tribunals are awarding the treaty formula of $\mathrm{FV}_{\mathrm{DE}}$ for expropriations in violation of the IIA-either without explanation (Group 1); because they believe that that amount is also the amount due for an expropriation in violation of the treaty (Group 2); or because the facts of the case make $\mathrm{FV}_{\mathrm{DE}}$ the most sensible award level, in particular because the asset has not increased in value since the taking (Group 3). ${ }^{68}$ Only three cases-ADC, Yukos, and Quiborax - have used the distinction to award a higher degree of damages than $\mathrm{FV}_{\mathrm{DE}}$, i.e., $\mathrm{FV}_{\mathrm{DA}}$ or something like it. ${ }^{69}$

One important wrinkle in these cases is that when tribunals purport to apply $\mathrm{FV}_{\mathrm{DE}}$, they are not consistent in whether they are using only information available at the date of the expropriation or information that has become available since that time, in particular when they are calculating the DCF of the investment. ${ }^{70}$ Though DCFs based on both available and ex post information are still discounted back to the date of expropriation in calculating $\mathrm{FV}_{\mathrm{DE}}$, those numbers can differ if market conditions change unpredictably after the expropriation. Full value on the date of expropriation using ex post information has been endorsed as early as Amco Asia v. Indonesia ${ }^{71}$ (which did not concern an IIA) and as recently at Quiborax. ${ }^{72}$ Both cases considered that amount to be the quantum of damages required for unlawful acts as a matter of customary international law. However, sometimes tribunals seem to rely on ex ante information for some inputs and ex post information for other inputs into $\mathrm{FV}_{\mathrm{DE}}{ }^{73}$ Academic and other

${ }^{68}$ I appreciate Charles Brower's point in this regard. See also the summary of the case law in $<8>$ UNCTAD < 8>, EXPROPRIATION: A SEQUEL, UNCTAD/DIAE/IA/2011/7, at 114-16 (2011).

${ }^{69}$ See Quiborax, supra note 1, paras. 54-56 (Stern, dissenting). As noted, an award on quantum has not been issued in ConocoPhillips. In Tenaris, supra note 48, paras. 542-49, the tribunal suggested that part of its valuation of certain side companies was based on Chorzów Factory and not merely the treaty.

${ }^{70}$ DCF is not always used, whether because an asset is no longer performing or because a tribunal regards data on cash flow as too contingent, in which case other methods to determine fair market value (e.g., share prices) are used.

${ }^{71}<8>$ ICSID $<8>$ Case No. ARB/81/1, paras. 613-14 (Nov. 20, 1984) [hereinafter Amco Asia].

${ }^{72}$ Quiborax, supra note 1, paras. 379-85. For other examples, see Christina L. Beharry, Lawful Versus Unlawful Expropriation: Heads I Win, Tails You Lose, in InVESTMENT TreATY Arbitration and International Law 185 (Ian A. Laird, Borzu Sabahi, Frédéric G. Sourgens \& Todd J. Weiler eds., 2016).

${ }^{73}$ See Quiborax, supra note 1, (Stern, dissenting). 
commentaries differ on whether ex post information can be considered for purposes of determining $\mathrm{FV}_{\mathrm{DE}}{ }^{74}$ I will return to this point in Part III.A.

\section{European Court of Human Rights}

A number of IIA tribunals have supported their distinctions between lawful and unlawful expropriations, with the consequences for damages, by reference to European Court of Human Rights (ECHR) jurisprudence. The precedent sometimes cited is Papamichalopoulos v. Greece (1995), where the Court, having previously found that the Greek military government's taking of the applicant's beachfront property was a violation of Protocol I, labeled the dispossession "unlawful." It then invoked Chorzów Factory and ordered Greece either to provide restitution or to pay the current value of the land and buildings (i.e., the $\mathrm{FV}_{\mathrm{DA}}$ ), as well as nonpecuniary damages for mental suffering. ${ }^{75}$

However, in Guiso-Gallisay v. Italy (2009), the Court, via the Grand Chamber, changed course significantly, ruling that when the state had definitively taken a claimant's property in the public interest such that she no longer had title to it, it need only pay the value as of the date of the expropriation (plus interest). ${ }^{76}$ The ruling suggested that some expropriations that violate Protocol I are worse than others, though it is hard to see how exactly it fits into the lawful/unlawful distinction. ${ }^{77}$ Investment tribunals do not, however, seem to have made reference to this case. ${ }^{78}$

\section{A Brief Word on Academic Commentary}

Contemporary academic treatments still make reference to the lawful/unlawful distinction as key to the determination of damages. Thus, the Dolzer/Schreuer volume and de Nanteuil's recent treatise restate the four criteria above as rules of customary international law, qualify any

74 Compare Irmgard Marboe, Calculation of COMPENSATION AND Damages IN INTERNATIONAL INVESTMENT LAW 237 (2009) and William C. Lieblich, Determining the Economic Value of Expropriated Income-Producing Property in International Arbitrations, $8 \mathrm{~J}$. INT'L ARB. 59, 72 (1991) with Abdala \& Spiller, supra note 14, at 109-18.

${ }^{75}$ Papamichalopoulos v. Greece (Article 50), App. No. 14556/89, 21 EHRR 439, paras. 3640 (1996). For cases citing it, see, e.g., Tidewater, supra note 66, at n. 218, and ADC, supra note 61, para. 497. The European Court of Human Rights has cited the case in some judgments under Protocol I-particularly those involving land or other physical assets - for the proposition that the state must provide restitution, or, failing that, $\mathrm{FV}_{\mathrm{DA}}$ plus nonpecuniary damages. Velcheva $\mathrm{v}$. Bulgaria, App. No. 35355/08, [2015] ECHR 552, para. 56 (2015); Borzhonov v. Russia, App. No. 1827/04, ECHR, para. 69 (2009); Brumarescu v. Romania, App. No. 28342/95, [1999] ECHR 105, para. 20 (2001).

${ }^{76}$ Guiso-Gallisay v. Italy (Just Satisfaction), App. No. 58858/00, ECHR, paras. 102-07 (2009).

77 See Octavian Ichim, Just Satisfaction Under the European CONVEnTion on Human RIGHTS 102-05 (2014). Unlike Ichim, I interpret Guiso-Gallisay as restoring somewhat the distinctions among expropriations based on the way they are carried out.

${ }^{78}$ It is not listed as an ECHR case cited by tribunals in the www.investorstatelawguide.com database, as of publication date. 
violation of those standards as an illegal expropriation, and call for recourse to the rules of state responsibility for such acts, which may lead to damages different from the value of the asset at the time of the taking. ${ }^{79}$ Both the latter and Marboe's impressive book also distinguish between compensation for a lawful expropriation with damages (indemnisation) for an unlawful act. ${ }^{80}$ Sornorajah agrees that takings must be for a public purpose and nondiscriminatory to be legal, but he does not seem to consider the mere nonpayment of compensation-even in violation of a treaty-to render the expropriation unlawful; and he calls for payment in those cases to be the amount in the treaty. ${ }^{81}$

\section{E. Crystallizing the Shortcomings in the Case Law}

This overview reveals contrasting understandings as to what makes an expropriation legal or illegal as well as a multiplicity of approaches to the damages that follow. For some tribunals, the distinction is not mentioned. For scholars and tribunals that do note it, an expropriation could be unlawful due to a breach of a contract, local law, customary law, or an IIA (the usage most common among tribunals today). If it is unlawful, the remedy still might be based on the standard in the treaty, i.e., $\mathrm{FV}_{\mathrm{DE}}$, or on customary international law. If it is the customary law standard, it might mean $\mathrm{FV}_{\mathrm{DA}}, \mathrm{FV}_{\mathrm{DE}}$, or something else, which may or may not incorporate information not known at the time of the expropriation.

The practice and case law makes clear that every expropriation differs in terms of the method used and the impact on the investor; and every investment differs in terms of the best economic way of valuing it. ${ }^{82}$ And not all treaties use identical language to describe the required compensation, although the use of $\mathrm{FV}_{\mathrm{DE}}$ is overall quite consistent. The problem for the law is that this diversity of expropriations does not map onto the diversity of legal approaches to remedies. There is no fit between the often-irreconcilable principles in the case law and the actions of the states, including their impact on foreign investors. The combination of

${ }^{79}$ Rudolf Dolzer \& Christoph Schreuer, Principles of INTERNATIONAL INVESTMENT LAW 99-100 (2d ed. 2012); ARnAud DE NANTEuIL, Droit International DE L'INVESTISSEMENT 342-47 (2014)

${ }^{80}$ See DE NANTEUIL, supra note 79, at 347-48; MARBOE, supra note 74, at 75-79. I will use the terms interchangeably in this piece. See also SERGEY RIPINSKY \& KEVIN WILliams, DAMAGES IN INTERNATIONAL INVESTMENT LAW 66, 86-88 (2008). For an argument that the BIT standard is close to that of customary law for unlawful takings, see Giorgio Sacerdoti, Bilateral Treaties and Multilateral Instruments on Investment Protection, 269 RECUEIL DES COURS 251, 396 (1997).

${ }^{81}$ MuthuCUMARASWAmy SORNORAJAh, THE INTERNATIONAL LAW ON FOREIGN INVESTMENT 406-10 (3d ed. 2010). See also JAMES CrAWFORD, BrownliE's Principles OF PubliC INTERNATIONAL LAW 624-25 (8th ed. 2012) (finding most expropriations "unlawful only. . . if appropriate compensation is not provided for," but some (e.g., discriminatory takings) unlawful per se, but then endorsing AIF's, supra note 26, economically flawed view on damage calculations).

${ }^{82}$ See Henry Weisberg \& Christopher Ryan, Means to Be Made Whole: Damages in the Context of International Investment Arbitration, in EVALUATION OF DAMAGES IN INTERNATIONAL ARBITRATION 165, 169-70 (Yves Derains \& Richard H. Kreindler eds., 2006). 
inconsistency and conceptual lack of clarity means that the case law does not provide legal guidance to participants in the foreign investment process.

The current approaches to remedies thus have a terminological and a substantive element. As a terminological matter, Chorzów Factory (and, to a lesser extent, the competing opinions in Amoco International Finance) still exerts a pull on some tribunals to characterize expropriations as lawful or unlawful, even if they do not use that distinction to determine damages. Tribunals seem to use the terms out of a sense of inertia, even though the only questions typically before a tribunal are: (a) whether an expropriation has taken place; (b) whether it met the criteria in the IIA; and (c) if not, the amount due for the treaty violation.

The terminological confusion has a fairly simple solution. Tribunals deciding expropriation claims under IIAs should describe expropriations as either treaty-compliant or treaty-violative. Whether the expropriation is unlawful in any other sense is not relevant for its consistency with the expropriation requirements of an IIA (except possibly to the extent that interpretation of some of the process conditions for expropriation may take account of customary international law). This terminology will avoid the incoherence of saying, for instance, that a violation of any of the first three (process-based) criteria of an IIA is an unlawful act while a violation of the fourth (payment) criterion alone is a lawful act.

Many tribunals use the term unlawful in this narrow sense of a treaty violation, so the term could be salvaged. But the alternative will also dispel misgivings by developing states that international law somehow questions their sovereign right to expropriate. ${ }^{83}$ By avoiding the moniker of "unlawful" in favor of treaty-violative, tribunals will be sending a clearer message that the state's right to expropriate is not at issue, but only whether the exercise of that right was conformity with treaties to which it is a party. ${ }^{84}$

But a terminological fix will not solve the more fundamental disagreement over the proper remedy for a violation of the criteria for a treaty-compliant expropriation. That dispute raises questions such as whether some violations of IIAs are worse than others; whether IIAs provide a lex specialis for remedies and thus the scope of the default rules of state responsibility; and how we ought best to monetize the damages for an expropriation.

\section{A FRAMEWORK FOR DEVISING REMEDIES IN INTERNATIONAL INVESTMENT LAW}

\section{A. Doctrinal Constraints?}

International law does not offer one obvious doctrinal solution to the problem presented here. Certainly, as a matter of customary international law, a breach of a legal obligation triggers duties by the violator, which the ASRs have identified as including cessation and nonrepetition, along with full reparation. The ASRs define the latter as restitution if possible (and not an undue

${ }^{83}$ A right that is beyond question. See, e.g., GA Res. 1803 (XVII) (Dec. 14, 1962).

${ }^{84}$ The terminology might have relevance in situations not covered by an investment treaty, e.g., where the investor or its home state bases its claims on custom (perhaps if an insurance contract only covers unlawful expropriations); or in interpreting other clauses of IIAs, e.g., an umbrella clause (where illegality for breach of a contract can be a treaty violation) or fair and equitable treatment (where the tribunal may have recourse to customary international law). 
burden on the violating state) or, otherwise, compensation "for the damage caused" (meaning "financially assessable damage including loss of profits"). ${ }^{85}$

But the ASRs do not provide enough guidance for investor-state tribunals for two reasons. First, ASR Article 33 makes clear that the obligations of the responsible state, including that regarding reparation, apply only to other states, and are "without prejudice to any right" enjoyed by a nonstate actor, such as a foreign investor. The tribunal in Wintershall Aktiengesellaschaft $v$. Argentina recognized this limitation in interpreting the jurisdictional provisions of the U.S.-Argentina bilateral investment treaty (BIT). ${ }^{86}$ Zachary Douglas has interpreted this provision, as well as parts of Chorzów Factory, as suggesting that certain forms of reparation are unique to the interstate context and that $<10>$ ICSID $<10>$ tribunals, which address what he calls "the vindication of private interests," may not have the authority to award the same damages to an investor as a state would receive. ${ }^{87}$ Brigitte Stern makes a related point that reparation can benefit only state interests and "perhaps private individuals," a position she grounds in human rights law. ${ }^{88}$

Wintershall's, Douglas's, and Stern's views on the inapplicability of Chorzów Factory and the ASRs regarding the consequences of breach - including the duty of full reparation - to the violation of investor rights have other arguments in their favor. For one, full reparation might not adequately reflect the current political economy of investor-state relations, where investors who sue might well be very sophisticated in terms of what they should have known about the possibility of expropriation; and states may strain to provide full compensation in the event of expropriations carried out in the national interest. I will return to this point in Part III below.

I need not decide whether all the ASR rules on consequences of a breach are inapplicable to investor-state arbitration. At a minimum, Article 33 leaves open the possibility that rules requiring full reparation might not apply to investors and affirms that if international investment law provides a lex specialis, then that law would prevail. ${ }^{89}$ Article 55 confirms that the ASRs do not apply if a lex specialis governs a state's responsibility. So, it is certainly possible for international investment law to have its own rules on consequences of a treaty breach, including recourse to the treaty standard for the quantum of damages. ${ }^{90}$

${ }^{85}$ Int'1 Law Comm'n, Articles on Responsibility of States for Internationally Wrongful Acts, Arts. 30-31, 35-36, UN Doc. A/56/10 (2001) [hereinafter ASRs].

${ }^{86}$ Wintershall Aktiengesellschaft v. Argentina, $<8>$ ICSID $<8>$ Case No. ARB/04/14, para. 113 (Dec. 8, 2008) (ASRs "contain[] no rules and regulations of State Responsibility vis-à-vis non-State actors.").

87 Zachary Douglas, Other Specific Regimes of Responsibility: Investment Treaty Arbitrations and $<8>$ ICSID $<8>$, in THE LAW OF INTERNATIONAL RESPONSIBILITY 815, 829 (James Crawford, Alain Pellet \& Simon Olleson eds., 2010); see also Zachary Douglas, The Hybrid Foundations of Investment Treaty Arbitration, 74 BRIT. Y.B. INT'L L. 183. For a critique, see CHARles LeBEn, THE AdVANCEMENT OF InTERNATIONAL LAW 54-61 (2010).

${ }^{88}$ Brigitte Stern, The Obligation to Make Reparation, in THE LAW OF INTERNATIONAL RESPONSIBILITY, supra note 87, at 563, 567. But see Martins Paparinskis, Investment Treaty Arbitration and the (New) Law of State Responsibility, 24 EUR. J. INT'L L. 617, 635-40 (2013) (offering arguments for extending ASR rules to investor-state disputes).

${ }^{89}$ ASRs, supra note 85, Art. 33 comm.

${ }^{90}$ See Vestey, supra note 60, paras. 327-29 (acknowledging this possibility). 
Second, even if a tribunal decides to use the ASRs to determine damages, the concept of compensation "for the damage caused," or Chorzów Factory's "wiping out all the consequences," is open to significant interpretation and does not point to a single answer regarding the date of valuation or the inclusion of other losses.

The result is three significant gaps in the case law and doctrine. It does not tell us: (a) whether international investment law has a lex specialis regarding damages for expropriations; (b) if so, what that lex specialis might require in terms of the quantum of compensation; and (c) if not, what "full reparation" means in the context of different sorts of expropriations.

\section{B. Toward a Coherent Framework}

One response to these gaps might be to leave things as they are on the understanding that investor-state tribunals' principal duty is to solve a dispute between two parties rather than develop any - or much - coherent case law. The origin of IIA-based arbitration in international commercial arbitration might support such a conclusion. Thomas Schultz has argued against consistency on the grounds that it can freeze bad law in place. ${ }^{91}$ Critiques of consistent legal reasoning across cases raise many questions beyond the scope of this essay; but for my purposes two brief, modest responses will suffice.

First, the various actors in the foreign investment process will benefit from some predictability from arbitral awards. In considering whether to conclude an IIA, a host state will understand what it is accepting if tribunals treat similar words in similar IIAs similarly. In case of a dispute between an investor and a host state, if the parties see how tribunals have handled cases using similar treaties, they will have a better sense of the strength of their claims and the desirability of settlement. Lawyers in disputes will, or at least should, be able to avoid relitigating settled issues. Other interest groups, whether labor unions or environmental activists, will also be able to make more coherent and persuasive claims. Arbitration itself will have more credibility if the damage award is grounded more firmly in legal principles and not seen as just picking a number between those offered by the parties. This sort of minimalist consistency, as opposed to an arbitral free-for-all, is essential to any rules-based system. ${ }^{92}$

Second, we must acknowledge that international investment law has many attributes of a public law system. Although the public/private divide is both overrated and fuzzy, it remains the case that, given the stakes for host states - the key repeat players - in adjusting national policies to IIA standards and in devoting significant resources to pay damages, the need for some predictability on key interpretive issues is essential. ${ }^{93}$ Even if-indeed, especially if - one favors retention of decentralized, party-controlled arbitration, investment law has become an area where stakeholders deserve some coherence in the law. More consistency will not allay many other

91 Thomas Schultz, Against Consistency in Investment Arbitration, in THE Foundations of International InVEstment Law: Bringing Theory into Practice 297 (Zachary Douglas, Joost Pauwelyn \& Jorge E. Viñuales eds., 2014).

92 See Jürgen Kurtz, Building Legitimacy Through Interpretation in Investor-State Arbitration: On Consistency, Coherence, and the Identification of Applicable Law, in THE FOUNDATIONS OF INTERNATIONAL INVESTMENT LAW, supra note 91, at 257, 269-75.

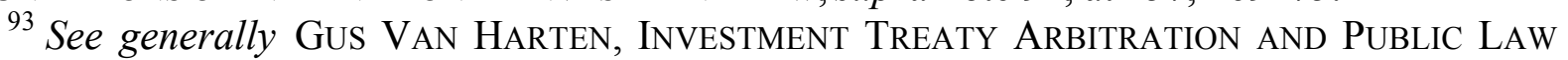
(2008). For an endorsement of some but not all of this characterization, see José E. Alvarez, Is Investor-State Arbitration “Public”?, 7 J. INT’L DiSP. SETTLEMENT 534 (2016). 
concerns of host states, e.g., the scope of IIA clauses on fair and equitable treatment, but it can contribute to a system with more acceptability from the key stakeholders.

If some improvement in the status quo is normatively desirable, one obvious doctrinal recourse would be to deploy principles of treaty interpretation in the hope that each IIA will reveal its own set of remedies for breach; or perhaps a common set of remedies will emerge for similarly worded clauses. The practice of states in response to treaty-violative expropriations when there is no arbitration, or the travaux préparatoires, might reveal a treaty-specific, regimespecific, or even a customary law remedy.

Although such an inquiry might yield some holy grail of remedies, it seems extremely doubtful. As for state practice under a treaty, states are unlikely to admit IIA violations if they do eventually pay compensation to investors, thus making it impossible to know whether the compensation paid "establishes the agreement of the parties"94 - i.e., of the host state and the investor's state as to the meaning of the treaty. And for the same reason, any compensation paid would be without opinio juris for purposes of customary law. Indeed, these same interpretive disputes arose over the relevance of ad hoc or lump sum settlements to the customary law standard of compensation. ${ }^{95} \mathrm{We}$ can look to judicial opinions and the views of publicists, but those are very source of the confusion.

With the case law inconsistent, the doctrine incomplete, and traditional methods of interpretation unhelpful, development of a framework for remedies could proceed from one of two bases. One, purely deductive and indeed philosophical, would seek to ground remedies in the theories of property, torts, contracts, remedies, and related matters, including global justicefor indeed all are relevant to expropriation. No doubt the ground is fertile for this sort of research.

The other, and the one I adopt here, is to focus on actual community expectations about remedies. ${ }^{96}$ That inquiry does not entail a search for an extant, agreed formula for remedies, because both the case law and state practice demonstrate that we do not yet have one. Instead, my theory looks for community expectations at the next level up, identifying the goals that decision-makers agree should be served by the remedies to investors for treaty-violative expropriations. Only if we understand the policy behind, and the point of, those remedies, rather than merely recite the "wipe out all the consequences" mantra, can we begin to have a sense as to what kinds of takings merit what kinds of payment. ${ }^{97}$ The result will be a framework for future arbitral decision making, as well as treaty-drafting. I hesitate to use the word doctrine for it suggests a rigidity and formulaic approach to resolving a highly complex set of decisions by

${ }^{94}$ Vienna Convention on the Law of Treaties, Art. 31(3)(b), May 23, 1969, 1155 UNTS 331.

${ }^{95}$ See, e.g., Sedco, supra note 25, at 184-89.

${ }^{96}$ See Higgins, supra note 19, at 321; Myres S. McDougal \& W. Michael Reisman, The Prescribing Function in the World Constitutive Process: How International Law is Made, in INTERNATIONAL LAW ESSAYS 355, 368 (1981).

${ }^{97}$ For an examination of the goals of remedies for human rights violations, see Szilvia Altwicker-Hámori, Tilmann Altwicker \& Anne Peters, Measuring Violations of Human Rights: An Empirical Analysis of Awards in Respect of Non-pecuniary Damages Under the European Convention on Human Rights, 76 ZEITSCHRIFT FÜR AUSLÄNDISCHES ÖFFENTLICHES RECHT UND VÖLKERRECHT 1, 10-12 (2016). For a critical work developing the concept of sanctioning goals, see Richard Arens \& Harold D. Lasswell, In Defense of Public Order: The Emerging FIELD OF SANCTION LAW 198-203 (1961). 
states, investors, and tribunals. Doctrine is what got us into this mess in the first place. So, while I aim for coherence and consistency, the model I propose can guarantee neither.

\section{Purposes of Remedies for Treaty-Violative Expropriations}

In my view, we can identify five goals of remedies as generally accepted by decisionmakers in and observers of the process of legal regulation of foreign investment. ${ }^{98}$ Decisionmakers might differ on how those goals should be operationalized, but I think the goals themselves are generally shared. Although they are not set out in any one document, case law and other discourse in the international investment community help us identify them. Beyond these five purposes, four goals are more controversial and contested.

\section{Repairing the Damage to the Expropriated Investor}

The first, and perhaps primary, purpose of a remedy for treaty-violative expropriations, or indeed compensation for any expropriations, is focused on the interests of, and losses to, the target of the taking. Whether or not the state was justified according to the relevant law (domestic or international), the investor has typically experienced a financial loss from the taking of its property. Seen from the perspective of property or tort theory or basic notions of justice, restitution or compensation is ordinarily due. ${ }^{99}$ Payment might be a redress for an illegitimate transfer or a means of legitimating it ex ante; but either way, the goal of payment is to offset or eliminate the loss the target of the taking has suffered. ${ }^{100}$ A remedy may also need to repair consequential harms associated with the property loss, such as the cost of abandoning the investment or even the costs of contesting the expropriation in court. This goal of repairing the loss does not equate with a guarantee of compensation-e.g., the investor may not deserve it for other reasons (such as, contributory fault), the investment may be worthless, or the state may have overriding interests that justify nonpayment-but the restorative function is central to a remedy.

${ }^{98}$ For a set of complementary goals of investor-state arbitration generally, see Sergio Puig, No Right Without a Remedy: Foundations of Investor-State Arbitration, in THE Foundations OF InTERnATIONAL INVESTMENT LAW, supra note 91, at 235, 243-48. See also Anne van Aaken, Shared Responsibility in International Law: A Political Economy Analysis, in DisTRIBUTION OF RESPONSIBILITIES IN INTERNATIONAL LAW 153, 158-61 (André Nollkaemper \& Dov Jacobs eds., 2015) (contrasting instrumental and noninstrumental goals).

${ }^{99}$ Peter Benson, Philosophy of Property Law, in THE OXFORd HANDBOOK OF JURISPRUdence AND Philosophy of LAw 752, 798 (Jules Coleman \& Scott Shapiro eds., 2002); Jules Coleman, Scott Hershovitz \& Gabriel Mendlow, Theories of the Common Law of Torts, in STANFORD ENCYClOPEDIA OF PHILOSOPHY, sec. 3.1 (Edward N. Zalta ed., 2015), at https://plato.stanford.edu/cgi-bin/encyclopedia/archinfo.cgi?entry=tort-theories; Joel Feinberg, Voluntary Euthanasia and the Inalienable Right to Life, 7 PHIL. PuB. AfF. 93, 102 (1978).

${ }^{100}$ Coleman \& Kraus, supra note 4, at 1337. 
The harm to the investor from a treaty-violative expropriation might be greater than the harm from a treaty-compliant expropriation. ${ }^{101}$ If the investor is denied some due process, or not paid on time or at all, it may experience additional harms beyond the loss of the property. These include the inability to invest the proceeds due the investor under a treaty-compliant expropriation or even mental harm (in the case of individuals) from abandoning the investment in an unpredictable way. So, remedies need to take into account any additional harm cause by a treaty-violative expropriation.

Despite differences among states over the precise amount an investor should be paid, the foreign investment law regime clearly recognizes this investor-oriented goal for remedies. ${ }^{102}$ The duty in countless IIAs on the state to compensate the investor - not its home state - in an amount equal to the $F V_{D E}$ is a recognition of the goal of repairing the harm to investors from all expropriations. Indeed, this goal is at the core of most international law approaches to remedies. Thus, the debates within both jurisprudence and the case law over remedies are focused on the question of what was really lost to the investor and how much compensation can repair that harm. And it is at the center of debates between arbitrators, whether in the Iran-U.S. Claims Tribunal or as recently as Quiborax, often using Chorzów Factory as a sort of trope.

Yet despite this emphasis on repairing the harm to investors, remedies serve other goals as well. While often not explicit in the case law (perhaps because arbitrators may see the elaboration of such considerations as ultra vires), these other goals are part of the community's expectations on remedies and must guide our choices.

\section{Putting the Correct Incentives on Host States}

A remedy for treaty-violative expropriations also serves a function oriented toward the taker, rather than the taken, one centered on placing certain incentives on host states. ${ }^{103}$ It puts an incentive on the state to follow the IIA's criteria when it does want to expropriate. Tribunals do not speak in terms of incentives, ${ }^{104}$ but it is clear that state responsibility for treaty violations, including damages, aims at providing them. ${ }^{105}$ Scholars have offered various theories for why states comply with legal obligations, whether in response to internal dynamics or external relations with other states. But it does not take a particularly imaginative theory to conclude that

${ }^{101}$ I am not assuming that the compensation paid in a treaty-compliant expropriation, i.e., $\mathrm{FV}_{\mathrm{DE}}$, eliminates the harm to the investor, as the investor may value the investment more than the $\mathrm{FV}_{\mathrm{DE}}$.

102 See, e.g., José Enrique Alvarez, The Public International Law Regime Governing International Investment, 344 RECUEIL DES COURS 54, 193, 231-32 (2011) ("the point is to make claimants whole for their losses"); Puig, supra note 98, at 245, 252 ("corrective" rationale); van Aaken, supra note 98, at 160.

${ }^{103}$ Indeed, the requirement in IIAs that the state pay for expropriation deters the taking of private property in the first place, just as the lack of such a requirement for bona fide regulations of a nonexpropriatory character signals that such measures are permissible (although the risk of an FET violation can interfere with this signal).

${ }^{104}$ For a suggestion that the purpose of the IIA expropriation provisions is to channel takings into particular methods, see Siag \& Vecchi, supra note 56, para. 428.

${ }^{105}$ See van Aaken, supra note 98, at 159-61 (noting also that absence of fault requirement serves a deterrence function). 
a duty to pay compensation for a treaty-violative expropriation, assuming it can be enforced, can affect state incentives to violate the treaty.

Moreover, it would also seem that to place the proper incentive on the state to comply with the treaty, the damages for treaty-violative expropriations should exceed the compensation for treaty-compliant expropriations; for otherwise the state would see no interest in complying. But, in fact, we cannot be sure, if only because states have other reasons-in particular reputational - to comply with IIAs than additional financial loss for noncompliance. ${ }^{106}$ Whether damages for the former must exceed the compensation for the latter in order to incentivize states to follow an IIA is ultimately an empirical question. ${ }^{107}$ (I will leave aside the broader question of whether an IIA, or compliance with it, promotes foreign investment, on which views differ greatly.)

Moreover, as economists have pointed out, goals (1) and (2) can sometimes conflict. Some remedies aimed at providing compensation to the target of a treaty-violative taking can over-deter, i.e., deter not merely violations but desirable conduct, by causing states to refrain from economically useful or efficient expropriations for fear of big payouts. ${ }^{108}$ It could also cause states to pull out of IIAs or $<10>$ ICSID $<10>$ or to ignore awards, anecdotal evidence of which can already be seen in the reactions of Argentina, Bolivia, Ecuador, and Russia to adverse rulings in investor-state arbitration.

\section{The Expressive Purpose of a Remedy}

Legal remedies can also serve an expressive function, a goal well accepted for domestic criminal law, but which is not limited to either criminal punishment or the domestic sphere. ${ }^{109} \mathrm{~A}$ remedy can express a societal view about the importance of the underlying legal norm, often a prohibition. But it can also express the efficacy of law itself, which seems critical in the case of international investment law. Remedies for treaty-violative expropriations send a signal to states, investors, and other actors in the foreign investment process that violations of treaties will not go unnoticed - that the law is, in a broad sense, operational and not merely a paper tiger. ${ }^{110}$ Thus, beyond the effect of compensation on the investor or the state, the meting out of consequences serves an independent goal, one that is essential to the integrity of the legal system. It is a

${ }^{106}$ See, e.g., Andrew T. GuZmán, How International Law Works: A Rational Choice THEORY 71-117 (2008).

${ }^{107}$ The state's prediction regarding whether the foreign investor will sue in response to a treaty violation will also affect incentives. See JAN PETER SASSE, An Economic AnALysis of BILATERAL INVESTMENT TREATIES 91-93 (2011).

${ }^{108}$ Id. at 100-01; see also Louis T. Wells, Double-Dipping in Arbitration Awards? An Economist Questions Damages Awarded to Karaha Bodas Company in Indonesia, 19 ARB. INT'L 471, 478 (2003); van Aaken, supra note 98, at 184, 186. High damage awards can also send economically inefficient signals to investors, as noted infra note 131.

${ }^{109}$ See generally Joel Feinberg, The Expressive Function of Punishment, in DoING AND Deserving: EsSAYS IN THE THEORY OF RESPONSIBILITY 95 (1970). On such theories in constitutional law, see Elizabeth S. Anderson \& Richard H. Pildes, Expressive Theories of Law: A Restatement, 148 U. PENN. L. REV. 1503 (2000). On international criminal law, see MARK Drumbl, Atrocity, Punishment, AND InTERnATIONAL LAW (2007).

${ }^{110}$ See Puig, supra note 98, at 235. 
profound expression of what the policy-oriented approach to international law calls "control.",111 This idea extends to many other contexts. For instance, if a state is required to pay dues to an international organization and pays them late, loss by the state of its vote in the institution's constituent assembly is more expressive of the law's efficacy than a requirement that it pay interest on a late payment. $^{112}$

Though the term may originate in American legal philosophy, the expressive purpose of a remedy is suffused into international jurisprudence. Recall that the PCIJ in Chorzów Factory said that it would be "unjust" for Poland to pay the same amount for expropriating German assets in violation of the 1922 treaty as it would if expropriation had been allowed under the treaty. ${ }^{113}$ Although morally the point makes little sense (is it really unjust in a philosophical sense?), the Court seems to be suggesting that violations of treaties, if unaddressed through remedies tailored to the violation, are threats to the possibility of law as a constraint on state action. In the Tehran Hostages Case, the International Court of Justice (ICJ) made a similar move in highlighting the consequences of continued flouting of both the Court's orders and the underlying diplomatic law. $^{114}$

\section{Maintaining the Viability of the International Legal Regime on Foreign Investment}

Remedies also need to advance the broader goals of the regime of which they are a part. This goal for remedies starts with a doctrinal premise - that remedies for breaches of the treaty should generally reflect the object and purpose of the treaty. This point has been recognized, albeit obliquely, by the ICJ in the Gabčikovo and Fisheries Jurisdiction cases. ${ }^{115}$ It also flows from the interaction of the Vienna Convention on the Law of Treaties (VCLT) and customary international law. Article 31 of the VCLT commands that interpreters of a treaty take into account its object and purpose. Because identification of a breach requires interpretation of the treaty, when a decision-maker classifies an act as a breach of a treaty, he or she will typically

111 See McDougal \& REISMAN, supra note 96, at 377-78.

112 See UN Charter, Art. 19. As evidence of the unwillingness of the UN's member states to enforce that sanction, see Rep. of the Comm. on Contributions, Seventy-First Session, UN Doc. A/71/11 (2016).

${ }^{113}$ See Chorzów Factory, supra note 5, at 47.

${ }^{114}$ U.S. Diplomatic and Consular Staff in Iran (U.S. v. Iran), 1980 ICJ Rep. 3, paras. 91-92 (May 24). The ASRs confusingly suggest that only cessation of unlawful activities serves this function and compensation is not mean to serve an expressive function; rather, only the remedy of satisfaction, can achieve that goal. ASRs, supra note 85, Art. 30, comm. para. 5; Art. 36, comm. para. 4; Art. 37, comm. para. 3. But this position represents a narrow understanding of the expressive function of a remedy. Indeed, restitution or payment of compensation in many ways offers a far stronger validation of legal rules than an expression of regret.

${ }^{115}$ Gabčíkovo-Nagymaros Project (Hung./Slovk.), 1997 ICJ Rep. 7, paras. 141-42, 150 (Sept. 25) (ordering parties to resume cooperation "that takes account of the objectives of the Treaty"); Fisheries Jurisdiction (U.K. v. Ice.), 1974 ICJ Rep. 3, para. 78 (July 25) (directing parties to find an "equitable solution derived from the applicable law," including treaties between them.) 
take into account the object and purpose of the treaty (except perhaps in the case of some very obvious facial violation). ${ }^{116}$

Now consider the implications of this conclusion for remedies. First, assume that the consequences of the breach arise under custom alone, with its overall requirement as one of "full reparation," or "wiping out all the consequences" of the breach. If the identification of the breach requires considering the treaty's object and purpose, then so should the identification of the remedy that will eliminate the consequences of the breach. Second, assume that the consequences of breaches arise under a lex specialis unique to that treaty. In that case, certainly that lex specialis must reflect the treaty's object and purpose just as the underlying primary obligations do. ${ }^{117}$ Either way, tribunals should devise remedies that respect a treaty's object and purpose.

In the case of IIAs, each treaty differs in its combination of investor rights and host state prerogatives. Yet, when viewed as a whole, the corpus of IIAs does share the purpose of creating a broadly accepted international legal regime on foreign investment. The proliferation of substantially similar bilateral and multilateral investment treaties suggests that most governments agree that some regulation of foreign investment is useful for promoting economic welfare in the host state. At the same time, the content of that regulation has changed over time, as the relative economic and political power of host states, home states, investors, and nonstate actors has changed. ${ }^{118}$ Just as the underlying rules reflect that political economy, so should the remedies for their violation. If they do not, some participants will decide they do not want to be part of that legal regulation, and the regime will unravel.

In particular, to maintain the viability of the regime, the remedies, like the rules, must take account of the profound changes in the regime since Chorzów Factory or TOPCO. We are no longer in a world in which the point of foreign investment law is to protect Northern investors against Southern host states. Rather, IIAs strike a balance between host state prerogatives and investor interests whose ultimate aim is the economic advancement of the host states. ${ }^{119}$ Contemporary IIAs and free trade agreements reflect a greater deference to host state concerns, as seen in the definitions of expropriation and fair and equitable treatment, and the exclusion of

${ }^{116}$ See Whaling in the Antarctic (Austl. v. Japan, N.Z. intervening), 2014 ICJ Rep. 226, paras. 55-58 (Mar. 31); ASRs, supra note 85, Art. 12, comm. para. 1.

${ }^{117}$ See generally DinAH SHELton, RemEdies in InTERnATIONAL HuMAN Rights LAw 97102 ( $2 \mathrm{~d}$ ed. 2005) (linking remedies to unique nature of human rights treaties). See also Chorzów Factory, supra note 5, at 47 (noting "aim of . . . the Convention" as preserving the property rights of Germans in Poland). Cf. Audley Sheppard, The Distinction Between Lawful and Unlawful Expropriation, in InVESTMENT ARBITRATION AND THE ENERGy CHARTER TREATY 169, 184 (Clarisse Ribeiro ed., 2006) (noting complete prohibition on expropriation in Chorzów Factory's scenario).

${ }^{118}$ For a review of those changes, see generally Steven R. Ratner, Corporations and Human Rights: A Theory of Legal Responsibility, 111 YALE L.J. 443 (2001).

${ }^{119}$ See, e.g., Free Trade Agreement Between the European Union and the Socialist Republic of Vietnam, draft agreement, Feb. 1, 2016, pmbl. (goal to "strengthen their economic, trade, and investment relations in accordance with the objective of sustainable development" and "raise living standards, promote economic growth and stability, create new employment opportunities and improve the general welfare ...") [hereinafter EU-Vietnam FTA]. 
certain domestic regulation from arbitration. ${ }^{120}$ When tribunals find expropriations, their approach to a remedy should respect the same balance or dynamic reflected in these treaties. This goal does not point to one solution regarding remedies for treaty-violative expropriations; but it suggests that any alternative to the status quo in the case law must take account of the interests, power, wealth, knowledge, and other features of the participants in the foreign investment process.

Some tribunals seem to have recognized this goal when they speak of interpreting IIAs in a "balanced" way, reflecting both investor and state interests. ${ }^{121}$ Others have invoked the need to take into account the expectations of the community of states regarding investment law, usually in the context of explaining their approach to earlier decisions. ${ }^{122}$ This goal also offers another perspective on why tribunals do not award restitution to investors beyond the obvious practical difficulties in enforcement (which tribunals obliquely recognize when they talk about the impossibility of enforcement of restitution). ${ }^{123}$ Such a remedy would frustrate a purpose of the IIA, which is to preserve the right of states to take foreign property, subject to conditions.

It might be questioned whether arbitrators themselves should take such a goal into account. In his Freshfields Lecture, Michael Reisman found it generally illegitimate for arbitrators to consider systemic goals in their deliberations, both because such considerations are not part of their interpretive mandate under the Vienna Convention and because the participants in the investment law system lack a shared vision of its goals. He fears that arbitrators will use these considerations to sacrifice principled decision-making for political expediency. ${ }^{124}$ Reisman is surely correct that arbitrators have different functions from those who draft treaties or analyze cases; their function is more backward-looking than forward-looking.

But inclusion of this goal is justified for two reasons with respect to remedies. First, the proposals I offer below can be developed in law through alternative means, e.g., new treaties or other modes of lawmaking. Second, even if arbitrators end up developing a new approach to remedies, systemic considerations are a legitimate consideration when the law has a lacuna, a point Reisman notes. This is indeed the case for remedies, where, as discussed above, the lawthe particular IIA and custom — do not provide a clear answer. In those cases, the judge may have reference to what Reisman calls "the community's law and agreed policies," including "the systemic implications of alternative elements of decision." ${ }^{125}$ Without exaggerating the degree of consensus among participants in the international investment law regime over its goals, the arbitrator can certainly consider whether some remedies would undermine confidence in that regime more than others.

${ }^{120}$ See, e.g., id., ch. 8.2, Arts. 14, 16, ann. on "Expropriation"; ch. 8.3, Art. 1.

${ }^{121}$ See, e.g., ST-AD GmbH v. Bulgaria, PCA Case No. 2011-06, Award on Jurisdiction, paras. 382-84 (July 18, 2013), and the cases cited therein.

${ }^{122}$ See, e.g., Noble Energy v. Ecuador, $<8>\operatorname{ICSID}<8>$ Case. No. ARB/05/12, Decision on Jurisdiction, para. 50 (Mar. 5, 2008).

${ }^{123}$ See, e.g., CMS v. Argentina, $<8>\operatorname{ICSID}<8>$ Case No. ARB/01/8, para. 406 (May 12, 2005) [hereinafter $C M S$ ]; ASRs, supra note 85, Art. 35, comm. para. 4.

${ }^{124}$ W. Michael Reisman, 'Case Specific Mandates' Versus 'Systemic Implications': How Should Investment Tribunals Decide?: The Freshfields Arbitration Lecture, 29 ARB. INT'L 131 (2013).

${ }^{125} I d$. at $149-50$. 


\section{Ease of Administration}

Lastly, any remedy, whether under customary law or a lex specialis, must be capable of administration by the tribunal determining damages. The general refusal to order restitution reflects arbitrators' realization that states will almost certainly not reverse course on something as important as an expropriation of foreign property. ${ }^{126}$ But ease of administration is not just about getting the host state to cooperate; it also requires that we develop modes that tribunals can implement given the information available to them. Although every award of damages involves discretion by the tribunal, the more a remedy requires recourse to a valuation method with highly complex, contested, or speculative elements, the more difficult it is for tribunals to determine a remedy and then justify it in their award. This challenge is compounded by the wild variations in valuations offered to tribunals by party-retained accounting firms.

Prediction will often be an element of valuation - it is the essence of the DCF methodbut some predictions are better than others. ${ }^{127}$ Tribunals already seek to advance this goal when they say, as they often do, they will not consider speculative damages, but the line between prediction and speculation is not always so clear. ${ }^{128}$ Given the need for awards to be understandable to the litigators, it is important to keep the arbitrators' mandate manageable when it comes to damage calculations.

\section{Other Arguable Goals for Remedies}

One might advance other goals for remedies for treaty-violative expropriation. Four are worth brief mention, along with the reasons they are not generally accepted.

\section{Economic Efficiency}

Law and economics literature is replete with analyses of the most economically efficient remedies for torts, contract breaches, and takings. ${ }^{129}$ These theories specify the damages or

${ }^{126}$ See, e.g., LG\&E Energy Corp. v. Argentina, $<8>$ ICSID $<8>$ Case No. ARB/02/1, para. 87 (July 25, 2007) (restitution beyond the power of a tribunal); Arif v. Moldova, $<8>$ ICSID $<8>$ Case No. ARB/11/23, para. 571 (Apr. 8, 2013); Christine Gray, The Different Forms of Reparation: Restitution, in THE LAW OF INTERNATIONAL RESPONSIBILITY, supra note 87, at 589, 595-96.

${ }^{127}$ In addition, if DCF requires that the tribunal consider only information known to the parties as of a particular date, then uncertainties arise not merely over prediction, but retrospection.

${ }^{128}$ ASRs, supra note 85, Art. 12, comm. para. 1; Art. 36, comm. para. 27; and cites therein. For a typical statement by a tribunal, see BG Group Plc. v. Argentina, $<8>$ UNCITRAL $<8>$, para. 428 (Dec. 24, 2007).

${ }^{129}$ Of particular relevance to expropriations, see e.g., William M. Landes \& Richard A. Posner, An Economic Theory of Intentional Torts, 1 INT'L REV. L. \& ECON. 127 (1981); Benjamin Hermalin, An Economic Analysis of Takings, 11 J. L. ECON. \& ORG. 64 (1995); Thomas S. Ulen, The Public Use of Private Property: A Dual-Constraint Theory of Efficient Governmental Takings, in TAKING PROPERTY AND Just COMPENSATION: LAW AND ECONOMICS Perspectives of the TAKINGs Issue 163 (Nicholas Mercuro ed., 1992). 
compensation that place the right incentives on various parties, spread the risks of harm efficiently, or strike the right balance between social costs and private costs; or the amount of insurance potential victims will and should purchase to protect against the risk of property loss. ${ }^{130}$ They have had a significant influence on the domestic law and scholarship of tort and contract damages. Economic approaches might suggest basing valuation of expropriated property on the minimum amount for which the investor would be willing to sell the investment (the "reservation price"), the amount for which he would buy insurance on the investment (the "implied insurance price"), or some other measure to encourage the state to engage only in economically efficient takings. ${ }^{131}$

Yet the case law shows that investment tribunals do not consider economic efficiency in the sense advanced by economists. Certainly, tribunals rely on economic concepts such as DCF to determine fair market value, and they rely on economic models to estimate future profits or prices for assets. But they do not look at incentives, social versus private costs, or other standards of economic efficiency. And neither of the dominant views in the case law about damages-i.e., $\mathrm{FV}_{\mathrm{DE}}$ or $\mathrm{FV}_{\mathrm{DA}}$ - is based on these rationales.

Practitioners and scholars of international investment law can lament this situation or praise it. Even those who favor an economic approach would then confront competing economic theories as to the best choice of damages. The lack of consensus on the desirability of economic analysis and its content seems destined to keep efficiency considerations out of the doctrine of remedies for IIA violations. ${ }^{132}$ This seems particularly true given the epistemic community of international arbitrators and its self-perceived goal of resolving a particular case. ${ }^{133}$ So however much we might view efficiency as a useful goal for remedies, it remains, at this point, a bridge too far for international investment law.

\section{Punishment of Violations}

Punishment of violations is the essence of criminal law and an accepted component of tort law in some countries for grievous torts. In the realm of international law, however, the formal doctrine still generally rejects punishment as a response to violations of legal rules. The ASRs, for instance, state in the commentary to Article 36, "[Compensation] is not concerned to punish the responsible State, nor does compensation have an expressive or exemplary character." 134 In fact, the case law and doctrine is more nuanced, with awards and some

${ }^{130}$ On the last point, see Philip J. Cook \& Daniel A. Graham, The Demand for Insurance of Protection: The Case of Irreplaceable Commodities, 91 QUARTERLY J. ECON. 144 (1977).

${ }^{131}$ For commentary invoking these insights in the international investment law context, see Alan O. Sykes, Economic "Necessity" in International Law, 109 AJIL 296, 321 (2015) (suggesting lower compensation for expropriated investors to prevent overinvestment in the host state); Wells, supra note 108, at 478-81.

${ }^{132}$ Though economists have examined the effect of IIAs on investment flows to host states, they have not addressed the effects of different remedies on the host state, investor, or investment flows. See generally The Effect of Treaties on Foreign Direct Investment: Bilateral Investment Treaties, Double Taxation Treaties, and Investment Flows (Karl P. Sauvant \& Lisa E. Sachs eds., 2009).

${ }^{133}$ See, e.g., Reisman, supra note 124.

${ }^{134}$ ASRs, supra note 85, Art. 36, comm. para. 4. 
scholarship endorsing the possibility of punitive awards, particularly with respect to international crimes. ${ }^{135}$

Yet in the realm of international investment law, at least, because states tend to justify their actions in terms of public interests, and those actions rarely involve a personal or physical harm to the investor, tribunals do not recognize any punitive goal, nor should they (even as we cannot discount the possibility that investment arbitrators act from such a perspective). Indeed, the ASRs' aversion to punishment for violation of interstate duties would seem to apply a fortiori to violation of duties by states to foreign investors. To the extent claims, arbitrators, or commentators might justify greater damages for so-called unlawful expropriations because they serve to punish the state for breaching the treaty, that rationale offers yet another argument against both the term itself and the automaticity of a larger damage award. ${ }^{136}$ In examining the options for remedies below, we will need to avoid those that are punitive.

\section{Unity of Remedies for Violations of International Law}

A third potential goal for remedies for expropriation is to achieve a consistency across doctrinal areas when it comes to violations of legal rules. For those concerned about fragmentation, a unified view of remedies, based on the ASRs, seems like one way to build coherence in the international legal order. Some investment tribunals seem to be influenced by this goal in their citation of ECHR cases, and in particular Papamichalopoulos, for the idea of $\mathrm{FV}_{\mathrm{DA}}$ as the appropriate remedy for a treaty-violative expropriation. ${ }^{137}$

Whatever the hopes for its proponents, such a unified approach has no place in the context of international investment law. First, as noted, the ASRs make clear that their reparation rules do not apply if the law has developed a lex specialis on the consequences of a breach. ${ }^{138}$ The ILC's 2006 study on fragmentation states that such special regimes - which it emphasized are in no way "self-contained"- are not a threat to the integrity of international law. ${ }^{139}$

Second, unity of remedies across regimes is particularly ill-suited for expropriations, which take place in numerous contexts and are adjudicated in diverse institutional settings. Different institutions have adopted distinct approaches to the existence of a taking - in particular, whether regulatory action crosses the line to a compensable taking-a trend that is not lamentable but rather necessary to advance the purposes of each institution and the regime it oversees. ${ }^{140}$ Just as a human rights regime might have a threshold for classifying governmental action as a taking different from that of the IIAs' investment regime, the former might well have need for different remedies compared to the latter. Human rights law protects property from

${ }^{135}$ Nina H.B. Jørgensen, A Reappraisal of Punitive Damages in International Law, 68 BRIT. Y.B. INT'L L. 247, 259-62 (1998).

${ }^{136}$ For one endorsement of punitive damages, see Sedco, supra note 25, at 204-05 and n. 40 (Brower, sep. op.).

${ }^{137}$ See, e.g., ADC, supra note 61, para. 497; Tidewater, supra note 66, para. 133, n. 218.

${ }^{138}$ ASRs, supra note 85, Arts. 33, 55.

${ }^{139}$ Int'l Law Comm'n, Fragmentation of International Law: Difficulties Arising from the Diversification and Expansion of International Law, paras. 152, 192-94, UN Doc. A/CN.4/L.682 (Apr. 13, 2006).

${ }^{140}$ Steven R. Ratner, Regulatory Takings in Institutional Context: Beyond the Fear of Fragmented International Law, 102 AJIL 475 (2008). 
certain intrusions by the state in the context of an overall goal of protection of individual rights and dignity, goals that are distinct from those of the investment regime. ${ }^{141}$ And investment insurance regimes, such as the Overseas Private Investment Corporation (OPIC), also advance different goals, including encouraging domestic companies to invest abroad, while also being financially self-sustaining, which might justify a sui generis standard for compensation as reflected in an insurance contract. ${ }^{142}$

Uniformity for its own sake thus ignores regime-specific goals, e.g., the fourth goal above with respect to remedies. Moreover, it fails to take into account that a remedy for takings in other regimes may also necessitate a different balancing of the goals, or the possibility of other goals. Thus, the specific approach that I endorse below will reach its limits in a different institutional context.

\section{Distributive Justice}

Finally, the case can be made that remedies should advance distributive justice, whether in rectifying North-South wealth inequities or those between some foreign investors and some developing states. In the pre-IIA era, the debates over compensation for expropriation, especially in the context of large-scale social changes, were intertwined with North-South debates about the legacy of colonialism. Some recent critiques of foreign investment law have criticized the substantive duties in IIAs and the process of investor-state arbitrations as exacerbating distributive injustices. ${ }^{143}$

Some of these critiques are quite persuasive, although I have argued that, under a conception of global justice oriented toward the protection of basic human rights rather than deep distributive justice, it is premature or overstated to claim that the foreign investment legal regime is unjust. ${ }^{144} \mathrm{~A}$ proposal for remedies for IIA violations based on advancing distributive justice would be useful for future lawmaking. For my purposes here, however, the key point is that deep distributive justice is not a goal shared by international investment law decision-makers. It is absent from the provisions of IIAs and not part of the considerations of arbitrators.

III. Evaluating Alternative Approaches to COMPensation For Treaty-Violative EXPROPRIATIONS

Having identified five goals of remedies for IIA violations, I now use those goals to appraise the three main alternatives for compensation. ${ }^{145}$ Drawing on the approaches taken by tribunals to date, I identify three possible options:

${ }^{141} C f$. Stern, supra note 88.

${ }^{142}$ See Ratner, Regulatory Takings, supra note 140, at 489-93. For an example of OPIC coverage, see Memorandum of Determination: Expropriation of Global Forestry Management Group (Russia), OPIC Contract of Insurance No. F339, at 8 (Apr. 16, 2011) (citing limitation in compensation and investor's duty to bear 10 percent of loss).

143 These critiques are summarized in STEVEN R. RATner, The THIN Justice of InTERnATIONAL LAW: A MORAL RECKONING OF THE LAW OF NATIONS 373-77 (2015).

${ }^{144}$ See id. at $352-73$.

${ }^{145}$ I will assume that restitution is not possible, an assumption justified by the remedies awarded even by tribunals invoking Chorzów Factory or the ASRs. 
(1) Any violation of the criteria for a treaty-compliant expropriation will trigger the level of compensation provided in the IIA - an approach that sees the treaty text as offering a lex specialis for damages. The cases in Group 1 in Part I.B above fall into this category.

(2) Any violation of those same criteria will trigger the customary law duty to provide full reparation, even as full reparation might be calculated different ways. The cases in Groups $2-4$ in Part I.B above fall into this category.

(3) Different violations of the IIA criteria will trigger different remedies.

None of these options requires a tribunal to use the confusing lawful/unlawful terminology. They each begin with the assumption that the state has breached the IIA and then offer alternatives for the possible remedy.

Other options for a remedy for treaty-violative expropriations are possible. Tribunals could ignore violations of the first three criteria, and instead provide remedies only for lack of payment. While tribunals have given states a large margin of appreciation on the public purpose criterion, ${ }^{146}$ ignoring the other criteria would signal that the treaty text is a nullity as far as they are concerned. Tribunals could also just assume or conclude that (1) and (2) are the same-that wiping out the consequences of the expropriation means simply paying the treaty formula of $\mathrm{FV}_{\mathrm{DE}}$ - as seems to have been done in the cases in Group 2 in Part I.B above. Although (2) might lead in some situations to compensation based on the $\mathrm{FV}_{\mathrm{DE}}$, an assumption that the customary international law standard for a violation and the IIA standard are the same is unwarranted. ${ }^{147}$

\section{A. A Valuation Primer}

Before explaining the three options, it is important to clarify several economic concepts, in particular because tribunals are often not explicit about them. For simplicity's sake, we may think of four points in the life of the investment dispute, at least with respect to an investment that is a going concern. D0 is the date the investment starts producing income; DE is the date of the expropriation; DA is the date of the award; and DT is the termination date, when the investment stops producing income, which will we, for the sake of simplicity, assume is after the date of the award. ${ }^{148}$ Thus:

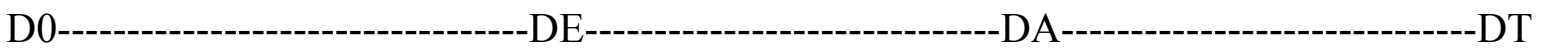

1. To reiterate a point made earlier, the full value of the investment at the date of the expropriation - $\mathrm{FV}_{\mathrm{DE}}$ - could mean one of two things: either (a) the value of the investment at

146 See August Reinisch, Legality of Expropriations, in STANDARDS OF InVESTMENT Protection 171, 178-86 (August Reinisch ed., 2008).

${ }^{147}$ Though beyond the scope of this paper, another option for tribunals is to provide a different remedy for large-scale nationalizations, as recognized by the World Bank Guidelines, World BANK, LEGAL FRAMEWORK FOR THE TREATMENT OF FOREIGN INVESTMENT: REPORT tO the Development Committee and Guidelines on the Treatment of Foreign Direct INVESTMENT, vol. II, at 43, princ. IV(10) (1992) [hereinafter WORLD BANK GUIDELINES].

${ }^{148}$ In some situations, the investment ceases to produce income at some time before DA, but the basic conclusions below remain the same. 
$\mathrm{DE}$ using information known at DE only, i.e., based on ex ante information- $\mathrm{FV}_{\mathrm{DE}}$ (ex ante); or (b) the value of the investment at DE using information known at DA, i.e., based on ex post information- $\mathrm{FV}_{\mathrm{DE}}$ (ex post). In the case of creeping expropriations, determining $\mathrm{DE}$ itself may be quite complex or it may be necessary to value the investment at a date other than DE. ${ }^{149}$

2. If $\mathrm{FV}_{\mathrm{DE}}$ means $\mathrm{FV}_{\mathrm{DE}}$ (ex ante), then it is calculated as the sum of: (a) the DCF from DE to $\mathrm{DT}$, as expected at $\mathrm{DE}$, discounted back to $\mathrm{DE}$; and (b) interest from DE to DA. ${ }^{150}$

3. If $F V_{\mathrm{DE}}$ means $F V_{\mathrm{DE}}$ (ex post), then it is the DCF from DE to DT, i.e., the sum of: (a) the DCF from DE to DA, based on information known at DA, brought forward to DA; and (b) the DCF from DA to DT, as expected at DA, discounted back to DA. ${ }^{151}$ Thus, this second version of $\mathrm{FV}_{\mathrm{DE}}$ - the ex post version-includes performance from $\mathrm{DE}$ to $\mathrm{DA}$ based on information known at DA, whereas the first version includes only the performance from DE to DA based on information known at DE.

4. These two versions of $\mathrm{FV}_{\mathrm{DE}}$ differ only if there are events after the expropriation that were not predicted at $D E$ that affect the DCF. If they had been predicted, they would have been priced into the $\mathrm{FV}_{\mathrm{DE}}$. But they can differ for many reasons, e.g., unexpected changes in commodity prices. $^{152}$

5. The full value of the investment at the time of the award- $\mathrm{FV}_{\mathrm{DA}}$ - is composed of two components: (a) the expected DCF from DA to DT, discounted back to DA, i.e., the discounted income stream after the award, as expected at $D A$; and (b) the accumulated income from DE to DA, i.e., the income from the expropriation to the award, brought forward to DA. ${ }^{153}$ If only (a) were awarded, the investor would lose the income between DE and DA. ${ }^{154}$

6. It is now clear that the $F V_{D E}$ based on ex post information is economically the same as the $F V_{D A}$. The two consist of the same two components: the actual performance from DE to DA, brought forward to DA (i.e., both 3(a) and 5(b) above), + the expected performance from DA to DT, discounted back to DA (i.e., both 3(b) and 5(a) above). ${ }^{155}$ As a result, when tribunals use ex post information to calculate the $\mathrm{FV}_{\mathrm{DE}}$, they are actually calculating - or at partially calculating - the $\mathrm{FV}_{\mathrm{DA}}$. Unfortunately, tribunals are often not clear about this move.

7. The key economic distinction, then, between $\mathrm{FV}_{\mathrm{DE}}$ (ex ante) and $\mathrm{FV}_{\mathrm{DA}}$ is whether we judge value based on the expectations at time DE only; or whether we judge value based on the

${ }^{149}$ For a proposal suggesting valuation well before the expropriation is complete, see W. Michael Reisman and Robert D. Sloane, Indirect Expropriation and its Valuation in the BIT Generation, 74 BRIT. Y.B. INT'L L. 115 (2004).

${ }^{150}$ The ex ante information is that known just before the expropriation, so it does not consider the expropriation's effect on the value of the investment.

${ }^{151}$ It is important to note that all DCFs after the expropriation must be calculated on the assumption that the investment remains in the hands of the investor. So even information known to the tribunal at DA must be information relevant to a valuation based on that assumption.

${ }^{152}$ For an example, see Valasek, supra note 23, at 23-31.

${ }^{153}$ As noted in note 151, the accumulated income is also based on the assumption that the investor still owns the investment.

${ }^{154}$ See, e.g., Abdala \& Spiller, supra note 14, at 107-08; Lieblich, Determinations by International Tribunals, supra note 31, at 43.

${ }^{155}$ The rate for bringing performance forward may differ from the rate for discounting future income back, but the equivalence remains the same. I appreciate clarification on this point from Amiyatosh Purnanandam and James Hines. 
information we have at $D A$ (both actual returns from the past and anticipated returns in the future). ${ }^{156}$ As will be seen below, this economic distinction is critical for evaluating valuation options. Indeed, the nub of the disagreement over how to treat treaty-compliant versus treatyviolative expropriations is over the treatment of information not available at DE. ${ }^{157}$

8. Finally, the formula in the typical IIA for payment to the investor must mean the $F V_{D E}$ based on ex ante information alone, i.e., the sum noted in number 2 above. This is the amount the state would have to pay the investor under the treaty at time DE. Obviously, the state could base its full valuation under the treaty only on the information it (or the market) had at the time. A treaty could not require payment of compensation based on actual future returns, information that was not yet available to the state or the investor. So, the treaty formula must be the $\mathrm{FV}_{\mathrm{DE}}$ (ex ante). ${ }^{158}$ However, tribunals that say they are applying the treaty formula and not some other value are often not clear about whether they are in fact using only ex ante information. When I use the term $\mathrm{FV}_{\mathrm{DE}}$ below, I am referring to the version based on ex ante information only.

\section{B. Option 1: Lex Specialis Within the Treaty-The IIA Formula for All Treaty-Violative} Expropriations

An award of compensation based on the IIA standard-FV $-\mathrm{FV}_{\mathrm{DE}}$ (i.e., $\mathrm{FV}_{\mathrm{DE}}$ (ex ante))represents a sort of built-in damages formula, under which the treaty itself specifies the consequences for its own violation. Awarding this amount in all situations advances some but not all of the goals of an expropriation remedy.

1. With respect to repairing the damage to the investor, in one sense this formula fairly considers the harm insofar as it could be said that the investor will receive the value of what was taken, plus interest. Neither the IIA violation itself, nor the character of the violation-i.e., whether the process conditions were violated in addition to the nonpayment of compensationhas an economic effect on the value of the asset. ${ }^{159}$ Economically, under the Capital Asset Pricing Model for valuing assets, the market price of the asset at a particular time requires the use of ex ante information alone because the market price of an asset reflects (predicted) risk and returns, not actual returns. ${ }^{160} \mathrm{We}$ might thus say that the investor's harm was confined to the value as known at that time, because the taking also removed the risk of loss from him (not merely the risk of gain). ${ }^{161}$

${ }^{156} \mathrm{FV}_{\mathrm{DA}}$ will exclude other damages that might be related to an expropriation, e.g., certain consequential damages.

${ }^{157}$ Cf. Kinnear, supra note 37, at 558-59.

${ }^{158}$ See the posting by James Searby in the $<8>$ OGEMID $<8>$ Virtual Seminar on Damages in Investment Arbitration - Session 3, Nov. 25, 2016.

${ }^{159}$ See Jan Paulsson, Ghosts of Chorzów: Maha Nuñez-Schultz v. Republic of the Americas, in INTERNATIONAL INVESTMENT LAW AND ARBITRATION: LEADING CASES FROM THE ICSID, NAFTA, Bilateral Treaties and Customary International LaW 777, 787-91 (Todd Weiler ed., 2005).

${ }^{160}$ For one summary of the Capital Asset Pricing Model, see Eugene F. Fama \& Kenneth R. French, The Capital Asset Pricing Model: Theory and Evidence, 18 J. ECON. PERSP. 25 (2004).

${ }^{161}$ See Franklin M. Fisher \& R. Craig Romaine, Janis Joplin's Yearbook and the Theory of Damages, 5 J. ACCT. AudiTING \& FIN. 145, 153-56 (1990); Beharry, supra note 72, at 211-12. 
Yet we could identify the harm differently - that what was taken was the ability to hold and dispose of an asset as the investor chose. ${ }^{162}$ Under that view, the investor lost the possibility that the asset might increase in value in a way that could not be foreseen at the time it was taken, and so the treaty formula is inadequate to repair the damage. Although the investor would lose that possibility even if the state had complied with the treaty-for all the investor can do in that scenario is reinvest the proceeds of the $\mathrm{FV}_{\mathrm{DE}}$ paid by the state-it remains the case that the state breaching the treaty has deprived the investor of that choice. In terms of risk-shifting, $\mathrm{FV}_{\mathrm{DE}}$ shifts the risk of future, unexpected loss in value to the state; but if the investment increases in value, the $\mathrm{FV}_{\mathrm{DE}}$ ends up depriving the investor of those gains.

A famous U.S. domestic analogy concerns the litigation over the abuse of trust by the executors of Marko Rothko's estate, who sold many of the artist's works shortly after his death in a self-interested deal. When Rothko's heirs sued for their recovery after the paintings had skyrocketed in value, the New York State courts awarded them the value of the paintings at the time of the trial and not the much lower value at the time they were sold. ${ }^{163}$ The appeals court distinguished the normal rule of trusts, under which a trustee who breaches the trust by selling property at an inadequate price is not liable for any appreciation damages, by noting that here the trustee had a duty to retain the property, so in that sense he "violated an integral condition of the trust ... [making the sales] inherently wrongful transfers which should allow the owner to be made whole." ${ }^{164}$ The similarity to Chorzów Factory is remarkable in the emphasis in both cases on the violation of an independent duty. Yet we can also ask whether the equation of treaty commitment with a trust, the violation of which allows for such appreciation-based damages, is justified. The heir betrayed by someone with a duty to act on the former's behalf seems harmed in a worse way than the foreign investor protected by a treaty commitment to take property only under certain conditions.

$\mathrm{FV}_{\mathrm{DE}}$ also seems inadequate if we view the protections of the IIA in terms of the jurisprudential concepts discussed earlier. In the terms put forth by Jules Coleman and Jody Kraus, we would say $\mathrm{FV}_{\mathrm{DE}}$ is the amount to legitimate a taking done in accordance with the three process-criteria (analogous in some ways to the amount due the victim under a liability rule). ${ }^{165}$ But the amount to legitimate a taking may well be inadequate —or, at least, is not necessarily adequate - as a measure of damages when the state does not act accordance with some or all of the four criteria. We may not know the correct measure of damages, but we can at least say that it should not be the $\mathrm{FV}_{\mathrm{DE}}$.

${ }^{162}$ See Lieblich, Determining the Economic Value, supra note 74, at 63. See also Thomas W. Merrill, Incomplete Compensation for Takings, 11 N.Y.U. ENVT'L L.J. 110, 119 (2002) (fair market value as neglecting subjective value to the owner).

${ }^{163}$ In re Estate of Mark Rothko, 43 N.Y.2d 305, 322 (1977) ("To make the injured party whole . . . since the paintings cannot be returned, the estate is therefore entitled to . . . appreciation damages."). These issues have arisen in contract law's treatment of post-breach events for valuation purposes, as seen in the UK House of Lords' decision in Golden Strait Corp. v. Nippon Yusen Kubishka Kaisha, [2007] UKHL 12 (Mar. 28).

${ }^{164} I d$. at 321-22.

165 See supra note 4. 
Moreover, the IIA formula falls short in rectifying some harms to the investor associated with the noncompliance with the treaty. The harms from lack of due process as well as unexpected departure costs and other consequential damages are not captured in it. ${ }^{166}$

2. With respect to correct incentives regarding compliance, this formula fares rather poorly. If the state pays the $\mathrm{FV}_{\mathrm{DE}}$ whether or not it complies with the treaty, with only interest to distinguish prompt payment from tribunal-ordered late payment, then, all other things being equal, the state has less incentive to comply with the IIA when it expropriates. ${ }^{167}$ States may have other incentives to comply with the treaty, such as the reputational harm from being a scofflaw or the need to attract foreign investment, but, ceteris paribus, a remedy that takes no account of the law violation enhances the likelihood of its repetition.

At the same time, payment of $\mathrm{FV}_{\mathrm{DE}}$, plus interest, should not generally incentivize a state to engage in so-called "opportunistic expropriation," "68 takings where the state believes it will profit more with the investment under its control than it would with the investment under the investor's control. The reason is that if the state and the investor both know that the investment is likely to generate more profits than originally expected, that expectation will be built into the $\mathrm{FV}_{\mathrm{DE}}$ even if it is paid later with interest. ${ }^{169}$ It is, however, possible that the state will know more than the investor, e.g., if it plans some regulatory changes after the takeover that will make the investment more profitable.

3. Regarding the expressive purpose, a remedy for treaty-violative expropriations based on the treaty formula signals that violations will not go unaddressed; for the state will still have to pay for its violation. However, $\mathrm{FV}_{\mathrm{DE}}$ does not send a special signal in terms of a sanction for the treaty violation, as opposed to the lack of payment. In that sense, it does not provide the same sort of control intention as would a rule based on a damages formula external to the treaty itself. Put another way, there is a certain sense of unclean hands when the state that goes outside the treaty by breaching it is required to pay only the amount specified in the treaty.

4. The internal treaty standard seems to advance the goal of a stable framework of international investment law accepted by a broad range of parties. When states agree to a treaty that specifies a formula for compensation for expropriation, it would seem to preserve confidence in the system if tribunals awarded compensation based on that formula. ${ }^{170}$ On the other hand, sophisticated host states ought to know that when they become parties to an IIA, they are agreeing to the possibility that a tribunal could award expropriation damages above $F V_{D E}$ for treaty-violative expropriations, and that if they wish to preserve $\mathrm{FV}_{\mathrm{DE}}$ as the sole formula for compensation, they ought to so specify in the treaty. And perhaps future IIAs will so specify. But for now, when host states are increasingly suspicious of investor-state arbitration, a strong case

${ }^{166}$ See Merrill, supra note 162, at 118.

${ }^{167}$ MARBOE, supra note 74, at 68.

${ }^{168}$ Valasek, supra note 23, at 3.

${ }^{169}$ Thus, in $A D C v$. Hungary, assuming the parties could have predicted that the airport would improve financially as a result of Hungary's entrance into the EU, then the $\mathrm{FV}_{\mathrm{DA}}$ should have been the same as the $\mathrm{FV}_{\mathrm{DE}}$. Indeed, the tribunal seems to rely on $\mathrm{FV}_{\mathrm{DE}}$ at a certain point in its valuation. See $A D C$, supra note 61, para. 507.

${ }^{170}$ See British Caribbean Bank, supra note 53, para. 261 (because article on expropriation was "specifically negotiated by the Parties of the Treaty .... there is no room for another method of evaluation of the compensation sought."). For an academic endorsement, see Sheppard, supra note 117, at 196. 
can be made that the treaty formula strikes a balance that will advance the durability of the system. This idea is expressed in arbitrator Stern's dissent in Quiborax, where she states that relying on $\mathrm{FV}_{\mathrm{DE}}$ (which she emphasizes should be determined only using ex ante information) represents a "fair interpretation of international investment law."171

5. Lastly, as for administrability, the treaty standard requires valuation of an asset at the time it was taken. Financial and valuation experts for the parties are working with, in essence, time-stamped (at DE) data on the market value of the asset, which may include a projection of revenue in the case of a going concern. ${ }^{172}$ As a general matter, this method, based on determining the expectations at DE, seems more difficult than one where the financial experts can consider economic data after DE, which may well account for some tribunals' willingness to use post-DE data. $^{173}$

In sum, the internal lex specialis approach, under which treaty-violative expropriations leads to an award of damages based on the treaty formula of $\mathrm{FV}_{\mathrm{DE}}$ (ex ante), plus interest to DA, advances one, or perhaps two, of the goals of a remedy - repairing the damage to the investor, if we to see that damages as limited to the value of the asset taken; and advancing the stability of the investment regime. But it does less well in terms of repairing the full harm to the investor, putting the right incentives on states to comply with treaties, and sending an expressive signal regarding the consequences of law violation, and it may be administratively difficult.

\section{Option 2: State Responsibility's Default Rules-Full Reparation for all Treaty-Violative Expropriations}

Reliance on the ASRs' concept of full reparation for damages - "wiping out all the consequences" in Chorzów Factory's famous phrasing - in the case of any treaty-violative takings meets some of the above-stated goals, but, as with the prior solution, not all. The difference between this option and Option 1 is the possibility for a tribunal to value the investment based on $\mathrm{FV}_{\mathrm{DA}}$ as well as to include other damages not reflected in the value of the investment.

1. Full reparation repairs the harm to the target if we see that harm as not merely the loss of an asset in the past. For when the state violates the treaty, it harms the investor by depriving him or her of the choice that the treaty provides to: (a) hold the investment and perhaps sell it later (i.e., the investor's choice if the state does not expropriate); or (b) invest the $\mathrm{FV}_{\mathrm{DE}}$ proceeds (i.e., the investor's choice if the state does expropriate). So, if the investor had held the investment and it appreciated, the state's treaty violation has deprived the investor of the opportunity to enjoy that appreciation - although the investor should not enjoy any appreciation due to the state's takeover of the investment (perhaps due to lower labor costs or new regulations). Damages based on $\mathrm{FV}_{\mathrm{DA}}$ allow for the possibility of this appreciation. While the investor's foresight in keeping or selling an investment, or investing the proceeds, should not be assumed to be perfect, this remedy reflects that loss.

${ }^{171}$ Quiborax, supra note 1, para. 56 (FV DA $_{\text {is }}$ "biased in favor of the investors"), 59, 102 (Stern, dissenting).

${ }^{172}$ See Charles N. Brower \& Jarrod Wong, General Valuation Principles: The Case of Santa Elena, in INTERNATIONAL INVESTMENT LAW AND ARBITRATION, supra note 159, at 747, 765-68 (discussing tribunal's decision to avoid ex post information).

${ }^{173}$ See, e.g., Yukos, supra note 6, paras. 1758-69. 
Valuation on the date of the award, using information known since the expropriation, thus reflects the reality that the loss is ongoing until the date of the award. And if damages are supposed to be a substitute for restitution, then the award date makes the most sense because that is when the property would be returned to the investor, as several tribunals have recognized. ${ }^{174}$ Though some may object that damages would then "vary with the date of the award,"175 that possibility is not normatively objectionable but inherent in the concept of fully repairing the wrong. (Indeed, total damages will change with the date of the award even when they are based on $\mathrm{FV}_{\mathrm{DE}}$ with interest, because of the accumulation of interest).

Yet what if the asset depreciates after the expropriation, due to factors not associated with the expropriation itself? Does full reparation then require an award of lower damages than the treaty standard of $\mathrm{FV}_{\mathrm{DE}}$ ? It could be argued that the investor should receive less than $\mathrm{FV}_{\mathrm{DE}}$, insofar as when the investment depreciates post-taking (due to forces beyond either the control of the state or the investor), the state's violation of the treaty deprived the investor of only the depreciated value. ${ }^{176}$ But this argument does not fairly describe the harm to the investor. Rather, the investor had a right, under the terms of the treaty, to the $\mathrm{FV}_{\mathrm{DE}}$. The investor's rights under the treaty make any subsequent depreciation not really "countable" for purposes of the harm, and thus the customary law rule of full reparation would seem to require setting the treaty standard of $\mathrm{FV}_{\mathrm{DE}}$ as a floor. ${ }^{177}$ This choice also means that the risk of loss is borne by the state if it violates the treaty. Another way to state this point is that the investor on the receiving end of a treatyviolative expropriation should not receive less than an investor who has experienced a treatycompliant expropriation. ${ }^{178}$

The result is the formula for full reparation introduced by Judge Brower in Amoco International Finance, which sets the $\mathrm{FV}_{\mathrm{DE}}$ (again, based on the ex ante information) as a floor on the remedy. ${ }^{179}$ By giving the investor the choice of $\mathrm{FV}_{\mathrm{DE}}$ and $\mathrm{FV}_{\mathrm{DA}}$, the Brower formula shifts the risk of depreciation of the asset to the state and the benefits of appreciation to the investor. This risk-shifting better addresses the harm to the investor from the state's deprivation of the choice described above and thus provides full reparation. ${ }^{180}$

${ }^{174}$ See Amco Asia, supra note 71, para. 186; Quiborax, supra note 1, para. 379. The classic citation to this effect is GEORG SCHWARZENBERGER, INTERNATIONAL LAW 666 (3rd ed. 1957) ("If restitution in kind were possible, it would have to take place as soon as possible after the judgment or award."); see also MARBOE, supra note 71, at 23; Herfried Wöss, Adriana San Román Rivera, Pablo Spiller, \& Santiago Dellepiane, Damages in International Arbitration under Complex Long-Term Contracts 267-68 (2014). Whether restitution is truly preferred over compensation remains unclear. See Yann Kerbat, Interaction Between the Forms of Reparation, in THE LAW OF INTERNATIONAL RESPONSIBILITY, supra note 88, at 573.

${ }^{175}$ Quiborax, supra note 1, para. 84 (Stern, dissenting).

${ }_{176} I d$., para. 103 (using this argument to show unfairness of full reparation under some circumstances).

${ }^{177}$ Abdala \& Spiller, supra note 14, at 118.

${ }^{178}$ I appreciate this point from an AJIL anonymous reviewer.

179 AIF, supra note 26, at 300-01, para. 18 (Brower, concurring).

${ }^{180}$ Abdala \& Spiller, supra note 14, at 108, 118; MARBOE, supra note 74 , at 132. But see Quiborax, supra note 1, para. 56 (Stern, dissenting) (arguing that this is biased in favor of investors). 
Full reparation also has the possibility of addressing the damage to the investor from the state's violation of the BIT's process conditions. That is, even if the asset has not appreciated at all and $\mathrm{FV}_{\mathrm{DA}}$ is nothing more than $\mathrm{FV}_{\mathrm{DE}}$ plus interest, a full reparation model can conceivably address the state's failure to respect these criteria. To offer a colloquial example, if a customer takes an item from a store and simply drops the cash equivalent of the price on the floor, we might say that the shopkeeper has been harmed for a failure to follow the procedures for buying merchandise. $^{181}$

In addition, the full reparation model allows for damages to include not merely the $\mathrm{FV}_{\mathrm{DA}}$, but consequential damages, i.e., incidental losses to the investor from the taking. The treaty formula does not do so.

Yet full reparation has drawbacks in terms of its calibration to the harm to the investor. First, consider the implications of this approach for violations of the fourth, payment condition typical of IIAs. The host state would have to pay extra damages above the FV $\mathrm{DE}_{\mathrm{DE}}$ even if it has paid or offered a payment to the investor, as long as that amount is less than the $\mathrm{FV}_{\mathrm{DE}}$ as determined by the tribunal. One could argue that a state should not be able to evade damages by offering an insufficient amount to the investor. But insufficient payment seems materially different from a failure by the state to pay anything at all, and the full reparation model does not capture that possibility. In Coleman and Kraus's terms, if payment according to the three process conditions legitimates the taking, then insufficient payment is at least closer to legitimating the taking than a deliberate refusal to pay, and the two scenarios should not be treated the same in terms of damages. The same could be said if the state has a bona fide dispute with the investor over who is the proper owner of the investment. Some tribunals and scholars have accepted this distinction by asserting that nonpayment of compensation is not always a violation of the IIA in the first place. ${ }^{182}$ Second, a state can violate the other three criteria in different ways, e.g., with insufficient process as compared to no process at all. Treating all violations the same in terms of the remedy ignores these nuances.

2. The full reparation model also seems better than the treaty formula at putting the right incentives on states to comply with the treaty. If we care not merely that states pay for assets that they expropriate, but keep the promises they have made-including the process conditions - then a full reparation formula offers a better incentive to comply. It requires states to internalize all the costs associated with the violation, including appreciation damages and consequential damages. States cannot merely pay late with interest.

3. Full reparation generally fills the gap in the expressive value left by reliance on the treaty formula. It sends a stronger message of the law's relevance by treating violations as not mere lapses to be corrected by late payment but as wrongs by the state to be assessed by reference to external standards of damages. But it treats violations in a binary way, ignoring possible bona fides by the state. It thus risks crossing the line from acceptable expression to impermissible punishment.

4. The full reparation formula, however, raises significant concerns regarding the goal of furthering the stability of the international investment legal regime. As shown from the examples above, a state can violate the treaty in numerous ways, with different effects on the investor. A

${ }^{181}$ I appreciate this example from Kyle Logue. Whether this can be quantified is a matter for item (5) below.

${ }^{182}$ See infra notes 189-190 and accompanying text (Tidewater, Venezuela Holdings, and ConocoPhillips); Quiborax, supra note 1, paras. 9-13 (Stern, dissenting). 
reparation formula that does not capture these nuances among treaty-violative expropriations risks upsetting the current expectations among many states regarding their right to expropriate. If tribunals routinely award $\mathrm{FV}_{\mathrm{DA}}$ (or $\mathrm{FV}_{\mathrm{DE}}$ based on ex post considerations) in a way that increases already large awards against developing states, it could exacerbate the backlash against IIAs.

Certainly, states are bound by agreements they have signed, including those that entrust the determination of violations and remedies to arbitrators. And host state claims that restrictions on their ability to expropriate are a violation of their sovereignty are clearly wrong as a matter of law (at least since Wimbledon). But expropriation remains a power of all states, and tribunals should be careful about offering remedies clearly associated with other unlawful acts when the state may have acted in good faith, albeit inconsistent with the IIA. As noted earlier, there is a good case that tribunals should not apply the Chorzów Factory/ILC reparation rules to investorstate disputes, and the ASRs themselves allow for special regimes of responsibility. The preservation of the system of IIAs through the confidence of all stakeholders is not advanced by requiring the state to pay to the foreign investor (especially one insured), in all circumstances, what it would have to pay another state. Thus, the risk to broad-based acceptability of the system is significant.

5. A full reparation regime also has drawbacks from the perspective of administrability. It requires a tribunal to determine a number of values that it need not under the treaty formula. First, in determining the $\mathrm{FV}_{\mathrm{DA}}$, the tribunal must not use the actual performance of the investment since the expropriation, but rather the performance assuming the investor still owned the investment, thus excluding any increased value due to the government's takeover. ${ }^{183}$ For the state should not have to compensate the investor for profits that the investor would not have made, just as the investor should not be prejudiced by a decline in value due to the expropriation. At least one tribunal, in Rumeli Telekom v. Kazakhstan, refused to award the investor for increased value caused by the state, but the practice does not seem pervasive. ${ }^{184}$ But it may prove difficult for a tribunal to determine whether the government did a better or worse job than the investor would have done in managing the investment. ${ }^{185}$

Second, if full reparation means the greater of $F V_{\mathrm{DE}}$ and $F V_{\mathrm{DA}}$, then the tribunal must determine both the $\mathrm{FV}_{\mathrm{DE}}$ and the $\mathrm{FV}_{\mathrm{DA}}$, which requires more accounting data (and arguments between the parties) than does the IIA formula. The Yukos tribunal managed - in eighty pages of reasoning - to perform this feat when valuation turned mostly on share prices, but others using DCF or other valuation methods might find this quite difficult. ${ }^{186}$ Third, the tribunal must determine consequential damages, i.e., costs to the investor from having to abandon its investment.

${ }^{183}$ This requirement offsets a normal advantage of calculating damages as of the date of the award, namely that one can use actual returns after the original loss. See Wöss et al., supra, note 174, at 268. (For indirect expropriations, the post-expropriation performance will need to assume the absence of those measures.) In the case of $\mathrm{FV}_{\mathrm{DE}}$, although the tribunal must assume that the investor remained the owner of the asset, it should be basing its calculations solely on information available at $\mathrm{FV}_{\mathrm{DE}}$ (or right before the expropriation became known), which would not reflect the possibility of increased (or decreased) profits due to a government takeover.

${ }^{184}$ Rumeli Telekom, supra note 43, para. 807-13.

${ }^{185}$ This challenge seems to be underestimated by MARBOE, supra note 74, at 37.

${ }^{186}$ Yukos, supra note 6, paras. 1782-824. 
Thus, full reparation does reasonably well at advancing the first two goals of a remedyreparation of harm (though it might overcompensate the investor if we see a state's underpayment based on a bona fide disagreement with the investor as a lesser harm) and incentives on the host state; but its binary approach to violations risks turning expression into punishment, it is deficient in terms of respecting the political economy of the international investment law regime, and it can be difficult to administer.

These concerns about Option 2 have significant implications for the continued relevance to international investment law of Chorzów Factory, which remains routinely cited by tribunals as the font of wisdom on remedies. Beyond the concerns noted earlier about the transposability of customary international law on remedies developed in the interstate context to investor-state disputes, and the economic anachronism of Chorzów Factory's valuation techniques, the above analysis underscores two key shortcomings of applying Chorzów Factory to IIA violations. First, its distinctions between lawful and unlawful expropriations, and its sweeping rule for remedies for the latter, are oblivious to the "infinite varieties" of the way a state may take property. And second, its demand to "wipe out all the consequences" of a treaty violation detracts from several critical purposes of a remedy.

Thus, whatever the merits of the full reparation approach to other regimes of international law, or as a default rule of custom, tribunals should stop assuming its relevance as a starting point for remedies in investment law. There is a certain irony here, for Chorzów Factory originated in an investment dispute; though it has come to stand for a much broader proposition in customary international law, it has also become quite outdated when it comes to the remedies needed in international investment law.

\section{Option 3: The Differentiated Approach: Tailoring Remedies to the Contours of the IIA Violations}

Under the third approach, the nature of the treaty violation determines the remedy. Rather than defaulting to either the treaty standard or the full reparation standard, the tribunal makes choices about remedies based on what the state has actually done in the course of its breach of the IIA. At this point I will assess this approach in terms of the five goals of remedies. I will not, for now, appraise any single formula that tailors remedies to treaty violations.

1. A differentiated approach repairs the harm to the foreign investor insofar as it links the conduct of the state in concreto, rather than the mere existence of a treaty violation, to the remedy. Investors can be harmed in different ways by treaty-violative expropriations (or even treaty-compliant ones). They may have faced an unfair process that did not allow them to contest the action; been the target of discrimination on racial, religious, or other arbitrary grounds; received partial payment, a promise of payment, or no payment. In addition, they may have incurred large expenses in contesting the action or terminating the investment (the latter of which they might incur in a treaty-compliant expropriation). Each of these violations has a distinct impact on the investor.

2. This approach can also create the incentives on states to comply with their treaty obligations. As noted above, Option 2 does this better than Option 1. At the same time, why should we assume that full reparation (whether $F V_{D A}$, or the choice between $F V_{D A}$ and $F V_{D E}$ ) provides the optimal set of incentives to induce compliance with the treaty? If a state refuses to pay $\mathrm{FV}_{\mathrm{DE}}$ but respects the process conditions, then we may be able to create an incentive for them to pay $\mathrm{FV}_{\mathrm{DE}}$ (i.e., comply with the treaty) by requiring them to pay the difference with 
interest, rather than insisting on damages equal to the $\mathrm{FV}_{\mathrm{DA}}$. If a state violates some but not all of the process conditions, a remedy tailored to that violation, as opposed to a default rule of $\mathrm{FV}_{\mathrm{DA}}$, might incentivize the state to follow the conditions they violate. A flexible approach may do better at providing the "sweet spot" in which we both fairly compensate the investor and provide the necessary incentives on states.

3. A differentiated approach can advance the expressive goal of a remedy. The importance of a treaty commitment can be reinforced without insisting that all violations are of the same gravity, i.e., the signal sent by uniform recourse to either the treaty formula or a full reparation rule. For example, a violation of the nondiscrimination criterion might well merit a particularly significant remedy; failure to pay $\mathrm{FV}_{\mathrm{DE}}$ due to unsuccessful negotiations between the state and investor would merit a lesser remedy. ${ }^{187}$

4. At a time when large awards against host states face resistance, any formula for damages beyond the compensation specified in the IIA raises significant concerns. The differentiated approach, insofar as it leaves open the possibility for a tribunal to set damages based on standards external to the treaty, also faces this shortcoming. Yet the possibility that tribunals might use the treaty formula for some violations, while reserving other, external formulas for other violations, mitigates these concerns somewhat. A differentiated approach might also afford more discretion to arbitrators than the earlier two options, which might produce opposition from host states and others concerned about the impartiality of arbitrators. ${ }^{188}$ On the other hand, arbitrators already have significant discretion in damage determinations. Thus, a differentiated approach contributes to the viability of the regime, but only if arbitrators are able to justify and tailor remedies so as to maintain the confidence of states.

5. Compared to the treaty formula, a differentiated remedy is more complex for arbitrators to administer in terms of the calculation of damages because it requires looking at more than just the ex ante determined $\mathrm{FV}_{\mathrm{DE}}$. Compared to full reparation, that standard could also be more complicated, insofar as a tribunal, instead of calculating the $\mathrm{FV}_{\mathrm{DA}}$ (or the $\mathrm{FV}_{\mathrm{DA}}$ and the $\mathrm{FV}_{\mathrm{DE}}$, under the Brower formula) and consequential damages, may have to monetize other impacts of the expropriation on the investor. How, for instance, does one put a monetary value on the failure of the state to follow due process?

In sum, the differentiated approach offers significant promise over the other two alternatives. It offers the possibility of tailoring the remedy for treaty-violative expropriations to the harm done to the investor while maintaining the right incentives on states to comply with the treaty. It fulfills the expressive function better than the ASR remedy. It offers flexibility for maintaining the confidence of various participants in the international investment law process. Yet it may prove difficult to administer insofar as some of the violations may be hard to quantify.

\section{OPERATIONALIZING A DIFFERENTIATED APPROACH TO REMEDIES}

${ }^{187} C f$. Les Laboratoires Servier, Biofarma, and Arts et Techniques du Progrès v. Poland, $<8>$ UNCITRAL $<8>$, PCA, para. 645 (Feb. 14, 2012) (tribunals have discretion to impose additional damages "to punish Treaty violations of particular seriousness, such as discrimination ... .."). See also id., para. 642 (suggesting normal remedy is the treaty standard, i.e., in Group 2 in Part I.B above).

${ }^{188}$ See generally CATHERINE A. Rogers, Ethics In INTERNATIONAL ARBITRATION 315-34 (2014). 
For the differentiated approach to further the goals of investment remedies consistently across cases, it will need to be specified at a higher level of detail. (Thus, while I believe tribunals must consider the five goals in order to arrive at a new framework, once that framework is adopted, it should be the basis for determining remedies.) Some movement is already afoot in this area, even as tribunals rely on the lawful/unlawful distinction. In ConocoPhillips $v$. Venezuela, the tribunal decided that an expropriation in breach of the Netherlands-Venezuela BIT would lead, under Chorzów Factory, to damages based on the $\mathrm{FV}_{\mathrm{DA}}$, but it interpreted the BIT's primary obligation of compensation to require only that the state engage in good faith negotiations, thereby implicitly acknowledging that some forms of nonpayment might trigger a different remedy from others. ${ }^{189}$ In Venezuela Holdings and Tidewater, the tribunals made a similar distinction between refusal of payment and an offer of payment or failed negotiations regarding amount of payment; in both cases, the tribunals held that the Venezuela did not violate the IIA, and awarded $\mathrm{FV}_{\mathrm{DE}}{ }^{190}$

None of these tribunals, however, explicitly adopted a differentiated approach to violations and remedies; they rather worked within the first two alternatives above and directed their interpretation to the IIA's primary obligation to compensate. That method has a significant flaw, however, in that it treats certain treaty breaches - notably certain types of nonpayment - as nonviolations. The IIA language on expropriations, however, is generally clear enough to make such an argument very strained. ${ }^{191}$

Indeed, it is conceptually flawed for a tribunal to find, as it did in Tidewater, that a bona fide disagreement over the $\mathrm{FV}_{\mathrm{DE}}$ is not a violation of the BIT and then to award the investor any compensation-how can there be compensation if there is no violation of the treaty? The tribunal's solution of viewing nonpayment as still provisionally lawful, and that the parties merely submitted to the tribunal the task of determining payment, is not consistent with the request for arbitration. ${ }^{192}$ Although the text of IIAs allows for significant interpretation by tribunals - notably whether an action is an expropriation in the first place - if a tribunal has determined that an act is an expropriation, the treaty provisions on compensation do not provide

${ }^{189}$ ConocoPhillips, supra note 63, para. 362. See also Sheppard, supra note 117, at 171 (calling an expropriation where only payment is lacking "provisionally lawful").

${ }^{190}$ See Venezuela Holdings, supra note 65, paras. 301-06; Tidewater, supra note 66, para. 145. $C f$. EnCana Corporation v. Ecuador, $<8>$ UNCITRAL $<8>$, LCIA Case No. UN3481, paras. 194-95 (Feb. 3, 2006) (nonpayment of a legally guaranteed tax refund does not amount in the first instance to an expropriation if the claimant has other options and act is not willful). The annulment committee in Venezuela Holdings did not question the Panel's finding that the expropriation did not violate the BIT.

${ }^{191}$ See, e.g., EU-Vietnam FTA, supra note 119, ch. 8.2, Art. 16 ("Neither Party shall . . . expropriate . . . except . . . against payment of prompt, adequate and effective compensation," further defined as the "fair market value of the investment at the time immediately before the expropriation or the impending expropriation became public knowledge."). A requirement of "just compensation" that did not mention $\mathrm{FV}_{\mathrm{DE}}$ might give arbitrators more interpretive maneuverability, but this was not the case in the four arbitrations mentioned. It is also possible that nonpayment is not per se a ground of unlawfulness under customary international law.

${ }^{192}$ See Tidewater, supra note 66, paras. 43-45, 55-57 (Claimants' arguments). 
for the interpretive space to say that payment includes nonpayment. ${ }^{193}$ Despite these difficulties, some commentators have suggested that mere nonpayment of compensation does not violate an IIA. ${ }^{194}$

Rather than misread the treaty language, tribunals should treat the different sorts of violations in the context of remedies. International investment law can thus develop a lex specialis with respect to remedies for treaty-violative expropriations, but not one confined to the internal treaty formula of $\mathrm{FV}_{\mathrm{DE}}$. At the same time, it will not be based on a default to the ASR formula. Rather, it can mix these elements and perhaps bring in others.

It might well be the case that tribunals are already engaging in this sort of approach below the radar, using their discretion with the final damages number to tailor the remedy to the nuances of the breach. ${ }^{195}$ If they are doing so, then the result is a significant disconnect between that endpoint and the reasoning used to get there. Although we might applaud a tribunal for striking a compromise acceptable to both parties, we should be less accepting of the lack of transparency in its reasoning. Indeed, arbitrators who seek acceptability for their rulings beyond the immediate parties should want an approach based on rules.

In developing the specific remedies associated with IIA violations, we must continue to keep in mind, and advance as much as possible, the five goals associated with remedies. Tribunals and scholars will disagree about how a remedy fares under each of the five factors and the weight afforded to each factor. The solution offered here is thus not the only possible approach, but it does what a remedy should do significantly better than the current approaches. The differentiated approach proposed below is meant to be adopted and administered by tribunals, but it is certainly feasible to consider incorporating it directly into future IIAs.

\section{A. Rejecting Economically Flawed Formulas for Remedies}

While the point may seem obvious, tribunals need to move beyond economically antiquated notions of damages for expropriations. In the era of modern finance, terms like damnum emergens and lucrum cessans simply have no place in international arbitration, even if civil law systems continue to use them. ${ }^{196}$ The mere usage of those terms in frequently cited cases such as Chorzów Factory or Amoco International Finance is not a reason for their retention when they lack an economic basis. They also risk the possibility of double counting of damages. ${ }^{197}$ It is unfortunate that they appear in some serious scholarship on expropriation. ${ }^{198}$

${ }^{193}$ Except in one extreme case-if the state offers $\mathrm{FV}_{\mathrm{DE}}$, as later determined by the tribunal, and the investor refuses to accept payment in the hope of getting more damages during arbitration, then in my view the state has not violated the treaty. I appreciate this point from Zachary Douglas.

${ }^{194}$ See MARBOE, supra note 74, at 58; RIPINSKY \& WILLIAMS, supra note 80, at 67; Reinisch, supra note 146, at 198-99.

${ }^{195}$ I appreciate this point from Rachael Kent.

${ }^{196}$ See John Y. Gotanda, Damages in Private International Law, 326 RECUEIL DES COURS 73, 105-11, 129-30, 145 (2007).

197 See, e.g., Jan Paulsson, The Expectation Model, in Evaluation of DaMAGES, supra note 82, 57, 62-65; Wells, supra note 108; Beharry, supra note 72, at 203-08.

${ }^{198}$ See, e.g., Sacerdoti, supra note 80; CRAWFORD, supra note 81. 
The World Bank Guidelines offer a useful, economically rational set of valuation methods for different sorts of expropriated investments. ${ }^{199}$

\section{B. FV $V_{D E}$ as the Remedy for Bona Fide Disagreements over Compensation}

When a state violates an IIA by not providing the compensation required by the treaty, i.e., $\mathrm{FV}_{\mathrm{DE}}$, but the violation was due to a bona fide disagreement between the host state and the investor over the $\mathrm{FV}_{\mathrm{DE}}$, and the state respected the process conditions for an expropriation, then the remedy for such a violation should be only the $\mathrm{FV}_{\mathrm{DE}}$ (i.e., based on ex ante information), plus interest to the date of the award. By bona fide disagreement, I mean situations where the state is committed to paying the treaty amount but has legitimate disagreements with the investor that have prevented payment. The most obvious cases would be where the host state makes a good faith calculation of $\mathrm{FV}_{\mathrm{DE}}$ that the investor rejects, or a there is bona fide disagreement about the identity of the legal owner of the investment, but the principle would apply to similar cases where the state still respects the process conditions. Thus, the host state's domestic law could require the government (or the investor) to follow certain administrative, judicial, or legislative procedures before payment is approved-which can serve as an important protection for the state's treasury. If those procedures have not concluded and the investor seeks recourse to investor-state arbitration, we can view the disagreement as bona fide assuming the state is still committed to paying and the delay is justifiable under the circumstances. ${ }^{200}$

With respect to the five goals I have identified:

1. This solution repairs the most significant damage to the investor, insofar as the only harm was not receiving the $\mathrm{FV}_{\mathrm{DE}}$ when it was due. The state did not harm the investor by ignoring the process conditions or rejecting the possibility of a remedy; it did not seek to deprive the investor of the ability to dispose of the asset or the proceeds as the latter chose in the future. The harm to the investor from mere nonreceipt of the amount due under the treaty, absent more aggravated circumstances, is repaired by the payment of $\mathrm{FV}_{\mathrm{DE}}$ plus interest. Payment of $F V_{\mathrm{DE}}$ completes the treaty-based process of expropriation and legitimates it.

As a conceptual matter, the idea of paying only the treaty amount for good faith failures to pay resembles the remedy that courts in the United States award when insurance companies fail to pay on their policies. If the failure is based on an incorrect but good faith interpretation of the contract, only the amount in the contract is awarded. If the company fails to pay in bad faith, then a greater amount is awarded (even as courts and commentators disagree on the sort of conduct that would justify additional damages and how much they should be). ${ }^{201}$

2. It puts the right incentive on states. States are incentivized to work with the investor in good faith in order to avoid higher damages. These negotiations, if successful, will prevent

${ }^{199}$ WORLD BANK GUIDELINES, supra note 147, at 41-42, principles IV(5)-(6).

${ }^{200} \mathrm{~A}$ separate question would be whether the $\mathrm{FV}_{\mathrm{DE}}$ determination arrived at by such procedures is entitled to any deference by an investor-state tribunal.

${ }^{201}$ See William S. Dodge, The Case for Punitive Damages in Contracts, 48 DukE L.J. 629, 636-41 (1999) (discussing key U.S. cases). The analogy is not perfect because the normal damages for breach of the contract, i.e., the amount specified in the contract, are based on the idea of expectation damages - which is akin in international law to full reparation - and the additional damages are generally considered punitive damages. In the case of an IIA, the additional damages beyond $\mathrm{FV}_{\mathrm{DE}}$ would be part of what is needed to make the investor whole. 
violations and ensure compliance, as well as prevent litigation. While it could incentivize states to offer insufficient amounts and then negotiate (for the most the tribunal would later order is $F V_{D E}$ ), limiting the $F V_{D E}$ option to good faith disagreements should constrain manipulation of the process.

3. It sends a signal that the law still matters-losing states still pay damages. At the same time, by treating a bona fide disagreement over payment and a state's clear flouting of the terms of the treaty differently, it expresses the idea that the law treats the former less severely than the latter and avoids a punitive outcome. The remedy reinforces the law's relevance even as it expresses a tolerance for legitimate disagreements between states and investors on the $\mathrm{FV}_{\mathrm{DE}}$.

4. It reflects the political economy of the foreign investment process and thereby promotes states' willingness to participate in the legal regulation of that process. It recognizes the failure to pay $\mathrm{FV}_{\mathrm{DE}}$ as a treaty violation, which respects the legitimate claims of home states and their investors; yet states' failure to achieve a meeting of the minds with the investor on the amount of the $\mathrm{FV}_{\mathrm{DE}}$ or other issues will not be condemned through a harsh remedy.

5. Concerning administrability, on the one hand, the proposed rule requires the tribunal to determine only the $\mathrm{FV}_{\mathrm{DE}}$. On the other hand, that process requires use of dated information, which might be difficult. More important, this proposal requires the tribunal to determine whether the state's failure to pay $\mathrm{FV}_{\mathrm{DE}}$ was due to a bona fide disagreement about the price, titleholder, or other factors. This task requires detailed analysis of the evidence regarding the parties' negotiations and ultimately a verdict on blame, if any, for the failure of payment. This process could extend the litigation. Yet Venezuela Holdings, Tidewater, and ConocoPhillips show that tribunals are capable of making such an inquiry. Those tribunals looked closely at the parties' interactions to conclude that in the first two, the state had acted in good faith, while in the last one, it had not. ${ }^{202}$

By offering a different remedy for one form of nonpayment than for others, even though both are treaty violations, this proposal is in tension with the ASRs, which do not link state responsibility and the duty of reparation to intent on the part of the state-leaving such questions for the primary rules - and provide only a limited set of circumstances precluding wrongfulness. ${ }^{203}$ Yet the ASRs recognize that reparation is, after all, for a harm and even (albeit incompletely) that a remedy should be proportional to the harm. ${ }^{204}$ So clearly less harm means less compensation. The idea of gradations of damages based on the severity of the violations has been accepted in other contexts. Notably, the Eritrea-Ethiopia Claims Commission argued that "the law of State responsibility must maintain a measure of proportion between the character of a delict and the compensation due." 205

Finally, it is worth considering whether a state's failure to compensate the investor because the former does not view its actions as an expropriation at all should be treated as a bona fide disagreement. In situations where the state denies that it is expropriating, it will probably not

202 ConocoPhillips, supra note 63, paras. 382-401; Venezuela Holdings, supra note 65, paras. 301-06; Tidewater, supra note 66, paras. 144-45.

${ }^{203}$ ASRs, supra note 85, Art. 2, comm. para. 10; Arts. 20-26. For example, I am not seeking to justify the lower payment on some claim of necessity by the state given the very narrow grounds of that excuse.

${ }^{204}$ Id. Art. 35, comm. para. 5; Art. 37(3); Art. 49, comm. para. 6 (limits of countermeasures).

${ }^{205}$ Eri.-Eth. Claims Comm'n, Final Award of Ethiopia's Damages, para. 312 (Aug. 17, 2009), at https://pcacases.com/web/sendAttach/767. 
provide due process or compensation. This case seems somewhat closer than the other bona fide disagreements noted above.

As for the harm to the investor, we could limit compensation to $\mathrm{FV}_{\mathrm{DE}}$ and address any additional harm from the violation of due process through proposal $\mathrm{D}$ below. As for incentives and the expressive value of a remedy, the possibility of paying only $\mathrm{FV}_{\mathrm{DE}}$ might incentivize states to use the indirect rather than the direct route to expropriations. But some governments reasonably believe that their regulations later determined by a tribunal to be expropriatory are not so, and $\mathrm{FV}_{\mathrm{DE}}$ thereby avoids a punitive element. From the perspective of the viability of the investment regime, limiting compensation to $\mathrm{FV}_{\mathrm{DE}}$ will reassure host states that their regulatory actions, even if ultimately found to be expropriatory, are not treated as outright refusals to pay. ${ }^{206}$

The countervailing concern here is administrability in terms of the tribunal's ability to determine the existence of a bona fide disagreement over the expropriatory nature of the government's acts. Tribunals would have to discern the seriousness of the host state's arguments that it was not expropriating indirectly, even though they have rejected those arguments on the merits. The tribunal would have to distinguish between obvious indirect expropriations and less obvious ones. Yet it is certainly possible for tribunals to reach such a conclusion, suggesting that overall, limiting payment to $\mathrm{FV}_{\mathrm{DE}}$ for such disagreements is justifiable.

Treating this situation as a bona fide disagreement may, in the end, prove unnecessary to address host state fears that tribunals will issue large awards for indirect expropriations. For tribunals have been increasingly wary of claims of such expropriations, adopting a test for the existence of an expropriation that centers on the loss of control and not merely a diminution of revenue. ${ }^{207}$ And more recent treaties contain a significantly narrower definition of expropriation. ${ }^{208}$ Thus, the primary rules seem to be the best site for addressing host state concerns about too many findings of indirect expropriations. ${ }^{209}$

C. For Outright Host State Refusal to Pay FV $V_{D E}$ A Choice for the Investor Between FV $V_{D E}$ and $F V_{D A}$

If a state fails to pay the investor due to a refusal to apply the treaty standard of compensation, then tribunals should give the investor damages equal to the $\mathrm{FV}_{\mathrm{DA}}$, which must exclude any appreciation that can be traced to the state's ownership of the investment, with a

${ }^{206}$ Indeed, some of these arguments might extend to a lower standard of payment for regulatory takings in all circumstances. For an economic argument to this effect, see Merrill, supra note 162, at 134-35.

${ }^{207}$ See generally Ratner, Regulatory Takings, supra note 140; see also Electrabel v. Hungary, $<8>$ ICSID $<8>$ Case No. ARB/07/19, para. 6.62 (Nov. 25, 2015) ("for both direct and indirect expropriation ... the requirement under international law [is] for the investor to establish the substantial, radical, severe, devastating or fundamental deprivation of its rights or the virtual annihilation, effective neutralisation or factual destruction of its investment, its value or enjoyment.").

${ }^{208}$ See, e.g., EU-Vietnam FTA, supra note 119, ch. 8.2, Art. 16, ann. on "Expropriation."

${ }^{209}$ Tribunals have much more often found some of these regulations to violate the treaty's standard of fair and equitable treatment, a point I address later. 
floor of $\mathrm{FV}_{\mathrm{DE}}$ (plus interest). ${ }^{210}$ Recall, however, that, in general, $\mathrm{FV}_{\mathrm{DA}}$ will only differ from $\mathrm{FV}_{\mathrm{DE}}$ if the investment performed in a way that could not have been predicted at DE. Although rarely used in practice, nor conditioned on excluding the state's contribution to the increased value of the investment, the choice between $F V_{\mathrm{DE}}$ and $F V_{\mathrm{DA}}$ is superior to the others in terms of the five goals of a remedy.

1. It provides the reparation that best matches the harm to the investor. The state has deprived the investor of the choice to hold the investment, sell it, or invest the proceeds, and the remedy needs to correct this harm. To do so, it needs to consider the value as of the date of the award based on information at that date. $\mathrm{FV}_{\mathrm{DE}}$ is justifiable as the floor because the investor was guaranteed that amount under the treaty, placing the risk of post-expropriation loss on the state breaching the treaty; but if the value has increased due to no action by the state, it must pay the (higher) $\mathrm{FV}_{\mathrm{DA}}$.

2. This proposal also places the right incentives on the host state. By shifting the risk of depreciation of the investment from the investor to the state, and the risk of appreciation from the state to the investor, it puts a strong incentive on states to carry out their treaty commitments. At the same time, the state does not pay the investor for the state's own contribution to the increased value, mitigating concerns that full value is punitive.

3. The expressive value of the remedy is also enhanced. By requiring the state to pay the investor potentially more than the $\mathrm{FV}_{\mathrm{DE}}$, it imposes a special consequence for ignoring the treaty, as opposed to simply misinterpreting the compensation requirement. It thereby reasserts the importance of the duty of compensation. Nonetheless, some host states may still view the difference between $\mathrm{FV}_{\mathrm{DE}}$ and $\mathrm{FV}_{\mathrm{DA}}$ as a form of punishment, especially if the additional amount is significant (though, as noted, the two numbers will often be the same). It is hard to combat such perceptions, but it is also important to note that damages above $\mathrm{FV}_{\mathrm{DE}}$ need not be viewed as punitive. ${ }^{211}$ In this case, the state has refused to pay and violated a core obligation of the IIA, so the better view seems to be that any difference is aimed to address the full harm to the investor rather than punish the state.

4. With respect to the viability of the legal regime on foreign investment, host state governments that believe investors win too often, or receive too much, will resist any remedies that go beyond $\mathrm{FV}_{\mathrm{DE}}$ (and even $\mathrm{FV}_{\mathrm{DE}}$ itself). In that sense, it is inferior to applying $\mathrm{FV}_{\mathrm{DE}}$ in all situations. ${ }^{212}$ But the limitation of this remedy to outright refusals to pay is superior to the alternative of awarding $\mathrm{FV}_{\mathrm{DA}}$ for any treaty-violative expropriation. Moreover, if tribunals justify their finding that a nonpayment is due to a refusal by the state and not a bona fide disagreement covered by the prior proposal, then the imposition of the risk-shifting remedy could sit better with host states.

5. As for administrability, this remedy is more complex than the other two insofar as it may require a calculation of $F V_{\mathrm{DA}}$ as well as $F V_{\mathrm{DE}}$. But tribunals will only have to engage in that calculation in a more limited set of cases than under an approach that awards the greater amount in the event of all treaty-violative expropriations.

${ }^{210}$ In situations where full reparation requires some amount other than $\mathrm{FV}_{\mathrm{DA}}$, e.g., in the case of a partial expropriation, that amount should be awarded.

${ }^{211}$ See Stephan Wittich, Punitive Damages, in The LAw of InTERnATIONAL ResPonsibiLity, supra note 87 , at 667,672 .

${ }^{212}$ See Quiborax, supra note 1, paras. 56-60, (Stern, dissenting). 


\section{A Case-by-Case Approach to Violations of a Treaty's Process Conditions}

A violation of an IIA's process conditions accompanied by payment of $\mathrm{FV}_{\mathrm{DE}}$ is unlikely to lead to litigation, so the likely scenario before a tribunal involves the state's breach of those criteria - typically the public purpose and due process requirements (especially the latter) - in addition to nonpayment. In principle, such a violation seems worse than the refusal to pay in isolation. Yet if the refusal to pay justifies a remedy of $F V_{D A}$ (with $F V_{D E}$ as a floor) for the reasons stated in the previous section, what additional damages should be awarded for failure to meet the process conditions? The five goals suggest that tribunals need flexibility on this issue.

1. Any additional harm to the investor from a violation of the process conditions would likely involve some sort of process-related mistreatment. ${ }^{213}$ Yet the sort of harm to the investor can greatly vary, and so the remedy should not replicate the approach for an outright failure to pay. Thus, the investor will need to demonstrate the specific harms from these violations to receive additional damages. One solution might be to award some expenses incurred in opposing the abuse of process. A more unconventional idea (that would require amending the IIAs) would be to award additional damages to the investor's state of nationality. If, for instance, the investor faced nationality-based discrimination, such discrimination harmed the investor's state as well.

2. With respect to incentives, an additional amount of damages gives the state an incentive to follow not merely the compensation requirement but the process conditions. States have put these criteria into IIAs, and they should not be treated as surplusage. Indeed, they are listed first in the typical treaty and offer an important measure of protection to the investor and, indirectly, to the investor's home state. Moreover, compliance with them can avoid tensions between the host and home state after an expropriation. Thus, the law should incentivize compliance with them.

At the same time, if, for some reason, the state pays $\mathrm{FV}_{\mathrm{DE}}$ but violates the process conditions, and the investor still decides to sue, these incentives argue against treating a violation of the process conditions as the same as an outright refusal to pay. Two reasons argue for a more flexible approach. First, although the host state must meet the process conditions to comply with the treaty, in reality the payment condition is the most important from the perspective of both the investor and its home state. Second, given the first goal of tailoring a remedy to the harm to the investor, and the possibility for a range of harms as noted earlier, incentivizing compliance by requiring the same remedy as an outright refusal to pay would seem punitive.

3 . With regard to the expressive purpose of a remedy, the possibility of additional damages sends the signal that IIA commitments are not merely about paying investors if they are expropriated, but about following certain standards in doing so. If the state violates those standards in addition to refusing the pay, the law is reinforced by an additional remedy.

4. Such a solution, like the prior one, raises concerns in terms of the reaction by losing parties. To enhance the proposal's acceptability to host states, tribunals must pay close attention to the legitimate concerns of host states in expropriating property. Thus, for example, the public purpose criterion should be broadly interpreted; discrimination should be limited to obviously invidious grounds; and the due process requirement should not involve importation of the procedural protections we might expect in a human rights regime. If arbitrators reserve the finding of process violations to unambiguous situations, then the possibility of additional

${ }^{213}$ Although the investor may have been harmed due to these acts by the state, I am not suggesting that the investor's human rights have been violated. 
damages may be acceptable to host states. ${ }^{214}$ In the end, tribunals may choose to refrain from adding anything to the damages - especially if $\mathrm{FV}_{\mathrm{DA}}$ turns out to be much higher than $\mathrm{FV}_{\mathrm{DE}}$.

5. In terms of administrability, this proposal places a great deal of discretion within tribunals as to whether to compensate for these violations, and how much. Determining the separate harm to an investor from the violation of the process conditions may be impossible in many situations. This challenge again underlines the importance of clear proof by the claimant of harm from the violation of those criteria.

\section{E. For Situations Other Than Bona Fide Disagreements over Payment, Payment of Demonstrable Consequential Damages}

Lastly, where the state has violated the treaty's process or payment conditions without any bona fide disagreement about compensation, then the state should have to pay consequential damages associated with the violation. These damages, recognized by tribunals and scholars alike, address the costs incurred by the investor as a result of terminating the investment under circumstances not provided under the treaty. ${ }^{215}$ They include costs associated with unanticipated or abrupt departure of personnel, unexpected transitions to government control or compliance with new rules, and perhaps even loss of reputation. ${ }^{216}$ (They do not generally include the legal costs of the arbitration or domestic remedies.) With respect to the five goals:

1. Consequential damages compensate the investor for unanticipated costs (even if, in practice, an investor can plan for or even insure against a breach of the treaty by the other side). At the same time, the investor should incur all the costs associated with an expropriation that is treaty-compliant, even if it objected to the expropriation. In those situations, the harm to the investor from the expropriation is, according to the treaty, fully covered by $\mathrm{FV}_{\mathrm{DE}}$. As for bona fide disagreements over the compensation, consequential damages should not be awarded because the situation seems close to compliance by the host state. Because the state has followed the process conditions and is committed in principle to paying the $\mathrm{FV}_{\mathrm{DE}}$, the investor is incurring only the expected costs of a treaty-compliant expropriation. If these disagreements include bona fide disputes over the existence of an expropriation, the state will not have followed all the process conditions, but on balance the good faith nature of the state's claim suggests nonpayment of consequential damages as well.

2. Compensation for consequential damages puts the right incentive on states insofar as those damages would not be due if the state had followed the IIA. Rather, the investor would have been expected to pay them. The exception for bona fide disagreements incentivizes good faith negotiations.

${ }^{214}$ I do not regard this as analogous to the manipulation of the primary rules regarding compensation that I criticized earlier, because in these situations, the text is open-textured enough to give the tribunal the discretion to avoid finding a violation of the process conditions.

${ }^{215}$ See, e.g., Siemens, supra note 62, para. 352; MARBOE, supra note 74, at 304-15 (collecting cases).

${ }^{216}$ See, e.g., Siemens, supra note 62, paras. 387-89; Unglaube, supra note 50, para. 307; on reputation, see Desert Line Projects v. Yemen, $<8>$ ICSID $<8>$ Case No. ARB/05/17, paras. 28991 (Feb. 6, 2008) (FET claims) [hereinafter Desert Line]; MARBOE, supra note 74, at 305-08. 
3. Consequential damages serve the expressive purpose of reaffirming the importance of expropriating only according to the IIA's procedures. A willingness to pay $\mathrm{FV}_{\mathrm{DE}}$ should be treated differently from outright rejection of the treaty's requirements.

4. Consequential damages might be resisted by host states, but the amounts are not likely to be so large that they threaten their commitment to the legal regime on foreign investment. In Siemens, the amount was $\$ 9$ million compared to $\$ 208$ million for the $\mathrm{FV}_{\mathrm{DA}}$; in Desert Line, it was one million dollars compared to the roughly $\$ 20$ million on the main claim. ${ }^{217}$

5. Lastly, consequential damages are relatively easy for tribunals to assess in that they typically do not involve complex determinations of market value but rather discrete expenses by the investor in connection with the treaty-violative expropriation. If the expense cannot be linked to the state's taking of the property, then tribunals will not award it.

This five-part proposal thus permits tribunals addressing expropriations to tailor remedies to the nature and severity of any IIA violations, while avoiding the conceptual confusions of the lawful/unlawful distinction and that between damnum emergens and lucrum cessans. It does a better job at advancing the purposes of a remedy than either the treaty standard for all expropriations or Chorzów Factory's full reparation standard. Although not unambiguously superior on all five goals, the proposal is nevertheless on balance clearly superior. We could even reduce it to three prongs: (1) $\mathrm{FV}_{\mathrm{DE}}$ for treaty-violative expropriations characterized by a bona fide disagreement between the parties about the compensation (including over the existence of an expropriation); (2) the higher of $\mathrm{FV}_{\mathrm{DA}}$ and $\mathrm{FV}_{\mathrm{DE}}$, along with consequential damages, for refusals by the state to pay compensation; and (3) a case-by-case approach to any damages for violations of an IIA's process conditions.

\section{F. Next Steps for Tribunals and Treaty-Drafters}

Tribunals adopting this approach, along with the secretariats that help draft their opinions, will need to make adjustments, both in shedding anachronistic terminology and in determining consequences for the violations of IIAs. Tribunals should be capable of distinguishing refusals to pay from nonpayments where the state and investor could not agree on the $\mathrm{FV}_{\mathrm{DE}}$. For the former situations, some tribunals-Siemens, ADC, Yukos, and Quiborax - have already awarded $\mathrm{FV}_{\mathrm{DA}}$, demonstrating that valuation of an investment as of that date is possible. With regard to violations of the process conditions, tribunals will be in new territory, as they have not focused on isolating damages due to violation of those criteria alone. Consequential damages, on the other hand, are remedies with which tribunals already have familiarity.

Will these new determinations by tribunals undercut the overarching goal of a more predictable and coherent case law? Compared to the current approach, the proposal seems like a significant improvement. We will have a rubric to connect remedies to the terms of the IIA and a more transparent framework that clarifies what losses to the investor should be compensated. Counsel and tribunals can focus on relevant questions about the actions of the host state and their impact on the investor: Did the state have a bona fide dispute with the investor over payment or the existence of an expropriation, or did it simply refuse to pay the treaty amount? Did any violations of the process conditions have an effect on the investor? Did the investor prove any consequential damages? These questions are more pertinent to remedies and more judicially

${ }^{217}$ Siemens, supra note 62, para. 403; Desert Line, supra note 216, paras. C.5, C.9 (converted to dollars). 
manageable than figuring out whether an action was lawful or unlawful as well as what the PCIJ meant in Chorzów Factory. On the damage calculations, valuation experts will still offer tribunals divergent figures, but claimants and tribunals can at least work from a generally shared appreciation of the economic concepts of $\mathrm{FV}_{\mathrm{DE}}$ and $\mathrm{FV}_{\mathrm{DA}}$. That understanding includes the need to exclude post-expropriation information from the former and include it in the latter, the limited circumstances in which the two numbers will differ, and the necessity of excluding from FV $\mathrm{DA}_{\mathrm{DA}}$ any unexpected increase in value due to the government's takeover.

Finally, the approach can be implemented with even greater predictability and authority if states incorporate it in the treaties themselves. Thus, we could imagine a new provision in IIAs, after the standard expropriation article, that tells a tribunal what to award when the state expropriates in a manner inconsistent with each of the four standard requirements. For instance, a new clause might say, "A state's failure to pay the amount specified in the fourth criterion [i.e., $\mathrm{FV}_{\mathrm{DE}}$ ] due to a bona fide disagreement with the investor [over a defined set of issues] shall not entitle the investor to damages beyond the $\mathrm{FV}_{\mathrm{DE}}$." Another could note that $\mathrm{FV}_{\mathrm{DE}}$ must be calculated, if at all possible, based on information known at DE. And another might say, "A tribunal may award consequential damages to investors if and only if they can demonstrate the additional expenditures due to failure to meet the third [due process] requirement." Along with reformed case law, any of these clauses would help move toward a true lex specialis for remedies for IIA violations. ${ }^{218}$

Yet, as noted earlier, this proposal is not simply transferable to a prescriptive process addressing a regime with different goals. It may well prove a poor fit for a human rights treaty or an investment insurance contract. Indeed, two or more states concluding an IIA might decide among themselves that expropriation should be compensated in yet another way, e.g., $\mathrm{FV}_{\mathrm{DE}}$ no matter what the circumstances of the taking.

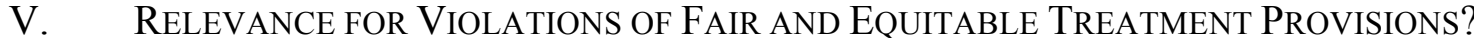

If we look beyond expropriations, the five goals for remedies identified above can also guide the choice of remedies for other IIA violations. The bulk of claimant victories today center on violations of the requirement that the state afford the investor fair and equitable treatment (FET), which treaties and tribunals increasingly define as the minimum standard under customary international law. As with expropriations, treaties do not specify damages for FET violations. Instead, tribunals have reflexively cited Chorzów Factory, trying to determine exactly what harm the FET violation caused the investor (in addition to the major interpretive disputes about the content of the customary law standard). ${ }^{219}$ Some tribunals have analogized FET violations to expropriations and used the treaty standard of $F V_{D E}$ to assess the damages for an FET violation. ${ }^{220}$ This last course of action seems odd insofar as the text nowhere contemplates $\mathrm{FV}_{\mathrm{DE}}$ as the damages for an FET violation but only as the compensation for an IIA-compliant expropriation.

${ }^{218}$ For further thoughts, see Rukia Baruti, Available Remedies in Investment Arbitration: Is There a Need for Explicit Provision in Investment Treaties? $<8>$ OGEMID $<8>$ Virtual Seminar, supra note 158.

${ }^{219}$ See the cases discussed in MARBOE, supra note 74, at 87-88.

${ }^{220}$ See Wena Hotels, supra note 40, para. 118; CMS, supra note 123, para. 410; see generally discussion in MARBOE, supra note 74, at 94-96. 
Although a full treatment of the proper formula for FET violations is beyond this study, the approach above suggests that neither $F_{\mathrm{DE}}$ nor $\mathrm{FV}_{\mathrm{DA}}$ should represent the exclusive remedies. FET violations need not deprive the investor of the full value of the investment. Rather, where an investor has been economically harmed by a violation of FET, but still retains control of the investment at time $\mathrm{X}$-which may be the date of the award or some point in the past when it sold the investment - tribunals should adopt a valuation method that identifies the difference between the value of the investment at time $\mathrm{X}$ and the value of the investment at time $\mathrm{X}$ in the absence of the FET violations (what I will call $\mathrm{FV}_{\mathrm{x}}$ ), while insisting that the latter value be proved with a high degree of certainty. ${ }^{221}$

The diminution in value approach seems to do well under the first three goals for remedies. The investor is effectively compensated for what it lost; the state is given a calibrated incentive to respect the FET provisions (although the tribunal could determine the content of that standard in a way that would send the wrong incentives to states, e.g., with regard to their regulatory power); and the treaty's expressive value is protected.

As for the fourth goal, maintaining the regime's viability, if the substantive standard for liability is set at the right level, and the award is calibrated to the difference in value, then in most cases the award will be short of $\mathrm{FV}_{\mathrm{x}}$ (or $\mathrm{FV}_{\mathrm{DA}}$ if the investor still holds the asset at the date of the award). But in those cases where the investor loses a large portion of the investment's value and the asset unexpectedly increases in value (not due to actions by the host state) after the FET violation, an award approaching $\mathrm{FV}_{\mathrm{DA}}$ may be a possibility; such an award could meet significant resistance from host states. Administrability may also be difficult because of the need to estimate the value of the investment in the absence of the regulatory measures, although tribunals have claimed to have done this. ${ }^{222}$

One way to address the fourth concern would be to cap damages at the full value on the date the FET violation began (plus interest), based on the information known at the time, on the theory that the host state should never be liable for more than the amount it would have had to pay the investor if it had totally taken the investment at that point. This approach would effectively analogize the FET violation to the bona fide disagreement over compensation in the case of expropriations, where $\mathrm{FV}_{\mathrm{DE}}$ is the upper limit of damages. Given the significant concerns of host states that their regulations may lead to investor-state arbitration and violations of the FET provisions of IIAs, this sort of cap could be useful. But if an FET violation is based on a deliberate violation of assurances meant to attract the investment in the first place - the standard, for instance, in Glamis Gold ${ }^{223}$ - the analogy to a bona fide disagreement seems strained, and it seems more like an outright refusal to pay.

So, as with expropriation, the method used by tribunals needs to be nuanced to the nature-not merely the existence - of the FET violation. And, as with expropriation, rote invocation of Chorzów Factory is a way of avoiding that nuance. Instead, tribunals could develop some principles, analogous to the ones I have developed for expropriations, that would calibrate damages to the severity of the FET violation, without crossing the line to punishing the

${ }^{221}$ For a recent case, see Micula v. Romania, $<8>\operatorname{ICSID}<8>$ Case No. ARB/05/20, paras. 944-48 (Dec. 11, 2013) (endorsing this method as flowing from Chorzów Factory).

${ }^{222}$ See id., paras. 950-1118.

${ }^{223}$ Glamis Gold, Ltd. v. United States, $<8>$ UNCITRAL $<8>$, para. 627 (June 8, 2009); see also Clayton and Bilcon v. Canada, $<8>$ UNCITRAL $<8>$, PCA Case No. 2009-4, paras. 445, 589 (Mar. 17, 2015) (reneging on "specific representations" triggers FET violation). 
host state. Because even reneging on assurances given to the investor can come in gradations, tribunals could take into account more explicitly what a reasonable investor should have expected in terms of risks, or the reasons the state reneged on its assurances. Good faith or lack thereof by the state should thus be relevant not merely to the identification of a violation of a primary rule, but to the damages as well. Consequential damages should be limited to those expenses completely unforeseeable to the investor. The investor's conduct should also be a relevant factor.

These sorts of principles could also be put into treaty text to clarify the factors that a tribunal may consider in determining damages for FET violations. At a minimum, a treaty could say that damages shall be limited to proven revenue directly traceable to the FET violation. But provisions that link the damages to the gravity of the FET violation-not merely whether it fell short of the Glamis (or other standard), but by how much - could also be helpful, as well as would a link between the damages and the conduct of the investor.

\section{CONCLUSION}

The differentiated approach provides tribunals with a new framework for decisionmaking that better advances the goal of remedies and allows them to tailor the remedy to the circumstances of expropriations. It takes seriously the decision of states to specify an amount the host state is obliged to pay in the IIA itself and the practice of many tribunals to award that amount. It also acknowledges the relevance of the concept of full reparation for treaty breaches while also moving beyond a simple doctrine - and one old PCIJ case - that does not capture when full reparation to a foreign investor is warranted. It builds on the distinction that some tribunals have made between bona fide disagreements over payment and a refusal to pay, as well as the practice of tribunals to award consequential damages when investors can prove them. In that sense, it offers a new, but not radical, step for tribunals. At the same time, by introducing new variables, this approach, whether by a tribunal or in a treaty, has its own risks to predictability. But given the enormous discretion tribunals already have when working under the ASRs reparation standard to arrive at a figure for damages, breaking the damages down more transparently would make for more persuasive awards.

The dissatisfying state of the case law on expropriation remedies, and the possibility for improvement through the approach offered here, also bring out some of the deeper structure of the rules of responsibility for violations of IIAs. Both of the status quo approaches $-F V_{D E}$ always and full reparation always - treat all the state's duties and violations the same notwithstanding the overall structure of the typical IIA's provisions on expropriation. Reparation through $\mathrm{FV}_{\mathrm{DE}}$ treats the investor-state relation as if the investor has a limited entitlement that allows the state to take the property as long as it paid $\mathrm{FV}_{\mathrm{DE}}$ (similar to a liability rule). And full reparation treats the investor-state relation as if even a relatively minor deviation from any of the treaty's terms is equivalent to a seizure of the investment. A choice between compensation based on the underlying primary rule - in the IIA - and the secondary rules - in the ILC's ASRsleaves tribunals with a narrow range of legal positions for remedies, even if they may exercise a great deal of discretion in coming up with the final number.

The differentiated approach thus offers a challenge to the separation of primary and secondary rules that has become accepted since the issuance of the ILC's ASRs. Though the ASRs do not rule out that each treaty or specialized regime can have its own rules on the consequences of a state's responsibility, the separation has limited the options for remedies. 
Investment law has not developed its own rules, and certainly not any sensitive to the primary rule that has been violated. The approach I offer links investor rights/state duties and remedies more directly, which is a particularly important for a regime under a barrage of criticism from both states and nonstate actors. For a relatively new area of international law to maintain its acceptability to this range of global participants, it needs to develop more nimble doctrines. Human rights law shows an alternative path, as it has evolved through new tools such as a recognition of the state's duties to protect against private violators, the margin of appreciation, and the acceptance of nonpecuniary damages.

In the end, the choice for states, and tribunals, is whether to rely on Chorzów Factory and the ASRs as the A and $\Omega$ - chronologically and metaphorically-for damages calculations, or whether to develop an alternative more attuned the reality of expropriations and other IIA actually as well as the goal of remedies. International investment law has now matured, as it were, so that we ought to be able to do better, either in case law or treaty text, in calibrating compensation to violations. It is time for a true lex specialis that makes clear to all the participants in the international investment law process the consequences if a host state - or a foreign investor-breaches its commitments under an IIA. 